\title{
Structural and Functional Characterization of Redox Mn and Co Sites in AIPO Materials and Their Role in Alkane Oxidation Catalysis
}

\author{
Björn Modén, ${ }^{\dagger}$ Laetitia Oliviero, ${ }^{\dagger, \downarrow}$ Jihad Dakka, ${ }^{\S}$ José G. Santiesteban, ${ }^{\#}$ and Enrique Iglesia ${ }^{*, \dagger}$ \\ Department of Chemical Engineering, University of California at Berkeley, Berkeley, California 94720 , \\ ExxonMobil Research and Engineering Company, 1545 Route 22 East, Clinton Township, \\ Annandale, New Jersey 08801, and ExxonMobil Process Research Laboratories, P.O. Box 2226, \\ Baton Rouge, Louisiana 70821-2226
}

Received: October 29, 2003; In Final Form: February 5, 2004

\begin{abstract}
The number of redox-active and inactive Mn and Co species in MeAPO-5 and MeAPO-18 (Me = Mn, Co) was measured from $\mathrm{H}_{2}$ consumption rates during $\mathrm{H}_{2}$ temperature-programmed reduction $\left(\mathrm{H}_{2}-\mathrm{TPR}\right)$, and their structure and oxidation state were probed at identical conditions by UV-visible and X-ray absorption spectroscopies. $\mathrm{H}_{2}$ consumption, loss of $\mathrm{Me}^{3+} \mathrm{UV}$-visible features, and a decrease in X-ray absorption edge energy occurred concurrently and at similar rates, indicating excellent agreement between these techniques. No $\mathrm{H}_{2} \mathrm{O}$ or $\mathrm{CO}_{2}$ were detected during treatment in $\mathrm{H}_{2}$ or $\mathrm{CO}$, respectively, indicating that reduction from $\mathrm{Me}^{3+}$ to $\mathrm{Me}^{2+}$ occurred by introduction of protons. These protons are fully removed by treatment in $\mathrm{O}_{2}$ to $773 \mathrm{~K}$, and $\mathrm{O}_{2}-\mathrm{H}_{2}$ redox cycles involving reversible proton formation suggest that cations reside within AlPO framework positions, in which protons reside as charge balancing cations at $\mathrm{Me}^{2+}-\mathrm{O}-\mathrm{P}$ bridges. $\mathrm{H}_{2}$ consumption rates measured during $\mathrm{H}_{2}$-TPR could be accurately described by Arrhenius-type behavior, and $\mathrm{H}_{2} / \mathrm{Me}$ ratios showed that only a fraction of all Me cations undergo reversible redox cycles. This fraction was 0.86 for MnAPO-18 (atomic $\mathrm{Mn} / \mathrm{P}=0.05$ ); it decreased from 0.68 to 0.40 for MnAPO-5 as $\mathrm{Mn} / \mathrm{P}$ ratios increased from 0.028 to 0.10 . For CoAPO- 18 with $0.028 \mathrm{Co} / \mathrm{P}$ and CoAPO-5 with $0.40 \mathrm{Co} / \mathrm{P}$, the fractions of redox sites were 0.64 and 0.40 , respectively. UV-visible spectra showed no detectable $\mathrm{Me}^{3+}$ features after thermal treatment in $\mathrm{H}_{2}$. Thus, cations that do not undergo redox cycles remain as permanently divalent cations throughout $\mathrm{O}_{2}-\mathrm{H}_{2}$ cycles. The redox-active fraction also decreased during repeated $\mathrm{H}_{2}-\mathrm{O}_{2}$ redox cycles above $773 \mathrm{~K}$, indicating that redox cations convert into permanently divalent sites. This conversion coincides with the evolution of $\mathrm{H}_{2} \mathrm{O}$ during $\mathrm{H}_{2}$ treatments above $773 \mathrm{~K}$. These findings together with the effects of $\mathrm{Me} / \mathrm{P}$ ratio on the redox fraction are consistent with a mechanism in which $\mathrm{OH}$ groups at divalent framework cation sites recombine to form $\mathrm{H}_{2} \mathrm{O}$ and an oxygen vacancy. Cyclohexanol and cyclohexanone formation rates during liquid-phase cyclohexane oxidation with $\mathrm{O}_{2}$ on MnAPO-5 samples increased linearly with the number of redox-active sites, suggesting that elementary steps of cyclohexane oxidation involve cycling between $\mathrm{Me}^{2+}$ and $\mathrm{Me}^{3+}$, and require cation sites able to reversibly form charge balancing cationic species.
\end{abstract}

\section{Introduction}

Aluminophosphate molecular sieves (AlPO-n) consist of $\mathrm{Al}^{3+}$ and $\mathrm{P}^{5+}$ tetrahedra linked by oxygen bridges. Their microporous crystalline structures ${ }^{1}$ can accommodate a wide range of substitutional cations within their framework. ${ }^{2-4}$ These materials (MeAPO-n) combine the useful catalytic reactivity of transition metal cations (e.g. Co and $\mathrm{Mn}$ ) with a shape-selective environment provided by small channels. $\mathrm{Mn}^{3+}$ and $\mathrm{Co}^{3+}$ framework cations have been implicated as active centers in selective oxidation ${ }^{5,6}$ and oxidative dehydrogenation ${ }^{7}$ reactions of alkanes, but direct evidence for specific effects of constraining channels is tenuous. Mechanistic details for these oxidation reactions remain controversial, but framework cations acting as redox centers to form radical-like intermediates are generally consid-

* To whom correspondence should be addressed. E-mail: iglesia@ cchem.berkeley.edu. Tel: +1510642 9673. Fax: +15106424778.

University of California at Berkeley.

$\doteqdot$ Current address: Laboratoire de Catalyse et Spectrochimie, University of Caen, UMR 6506, ISMRA, 6 bd Maréchal Juin, 14050 CAEN Cédex France.

$\S$ ExxonMobil Research and Engineering Company.

\# ExxonMobil Process Research Laboratories. ered, ${ }^{6,8}$ mostly on the basis of heuristic arguments and chemical analogies with homogeneous oxidation processes.

Recent reviews have described spectroscopic data (UVvisible, X-ray absorption, ${ }^{27} \mathrm{Al}-$ and ${ }^{31} \mathrm{P}$ NMR, electron-spin resonance) that probe the structure and electronic properties of cations in AIPO materials. ${ }^{2-4}$ Active cations isomorphously substituted in AIPO frameworks have not yet been directly or unequivocally connected with specific structures involved in redox cycles required for oxidation turnovers, even after significant attention and continuing debate. To some extent, the structural complexity arising from multiple cation types and from ubiquitous changes in cation valency during treatment and catalytic turnovers prevent any one spectroscopic method from providing a rigorous assessment of cation speciation and catalytic relevance. Quantitative chemical methods have proven essential to provide such information for cation-modified aluminosilicates, ${ }^{9}$ but they have not been rigorously used for cation-modified aluminophosphate materials.

Here, we combine chemical analysis methods, which measure extents of reduction from the chemical composition of effluent streams during treatment or catalytic reactions, with in situ UV- 
TABLE 1: Elemental Analysis of as Prepared MeAPO Materials

\begin{tabular}{|c|c|c|c|c|c|c|c|}
\hline \multirow[b]{2}{*}{ catalyst } & \multicolumn{3}{|c|}{$\begin{array}{c}\text { atomic fractions } \\
\mathrm{X} /(\mathrm{Me}+\mathrm{Al}+\mathrm{P})\end{array}$} & \multicolumn{3}{|c|}{ atomic fraction } & \multirow{2}{*}{$\begin{array}{c}\mathrm{Me} \\
\mathrm{Wt} \%\end{array}$} \\
\hline & $\bar{X}=\mathrm{Me}$ & $\mathrm{X}=\mathrm{Al}$ & $\mathrm{X}=\mathrm{P}$ & $\overline{\mathrm{Me} / \mathrm{P}}$ & $\mathrm{Al} / \mathrm{P}$ & $(\mathrm{Me}+\mathrm{Al}) / \mathrm{P}$ & \\
\hline MnAPO-5-1 & 0.027 & 0.482 & 0.491 & 0.055 & 0.982 & 1.037 & 2.0 \\
\hline MnAPO-5-2 & 0.014 & 0.486 & 0.500 & 0.028 & 0.972 & 1.000 & \\
\hline MnAPO-5-3 & 0.049 & 0.462 & 0.489 & 0.100 & 0.945 & 1.045 & 3.6 \\
\hline MnAPO-18 & 0.025 & 0.476 & 0.499 & 0.050 & 0.954 & 1.004 & 1.83 \\
\hline & 0.020 & 0.497 & 0.482 & 0.041 & 1.031 & 1.073 & \\
\hline CoAPO-18 & 0.014 & 0.494 & 0.492 & 0.028 & 1.004 & 1.033 & 1.08 \\
\hline
\end{tabular}

visible and $\mathrm{X}$-ray absorption spectroscopic methods during treatment in streams containing $\mathrm{H}_{2}$ or $\mathrm{O}_{2}$. In the process, we measure the fraction of the $\mathrm{Co}$ and $\mathrm{Mn}$ atoms present in MeAPO materials that undergo reduction and oxidation in various chemical environments and also the extent to which these cycles are reversible. Concurrent in situ spectroscopic assessments allow unambiguous assignments of specific spectral features to a given species, structure, or oxidation state. Cyclohexane oxidation turnover rates are measured on these materials and related quantitatively to the number of various $\mathrm{Mn}$ or Co cation structures in each sample to determine which cation species act as catalytic sites and to confirm the redox requirements for catalytic oxidation sequences.

\section{Experimental Methods}

Synthesis and Characterization of MeAPO Samples. CoAPO-5 and MnAPO-5 samples were prepared using procedures previously described. ${ }^{10}$ AlPO-18 and Co- and MnAPO18 were prepared as described by Chen et al. ${ }^{11} \mathrm{Co}$ and $\mathrm{Mn}$ were introduced as divalent cations during synthesis to give $\mathrm{Co} / \mathrm{P}$ or $\mathrm{Mn} / \mathrm{P}$ atomic ratios of $0.028-0.10$. Thermal treatments were carried out using dry air (Airgas, zero grade), purified using a 13X sieve at ambient temperature, by heating samples to 393 $\mathrm{K}$ at $0.167 \mathrm{~K} \mathrm{~s}^{-1}$, holding for $1 \mathrm{~h}$, and then heating to $823 \mathrm{~K}$ at $0.05 \mathrm{~K} \mathrm{~s}^{-1}$ and holding for $3 \mathrm{~h}$. The chemical composition of the samples was measured by inductively coupled plasma emission spectrometry, and the results are shown in Table 1. $(\mathrm{Me}+\mathrm{Al}) / \mathrm{P}$ atomic ratios differ slightly from the value of unity expected from structurally pure $\mathrm{Me}_{x} \mathrm{Al}_{1-x} \mathrm{PO}_{4}$, although the differences are within the limits of error. All MeAPO-5 and MeAPO-18 samples showed X-ray diffraction patterns for the expected crystal structure. ${ }^{12,13}$ Very weak diffraction lines for trace crystalline impurities were detected only in CoAPO-5; these appear at angles corresponding to the most intense lines for AlPO-18, indicating the presence of $\sim 1 \%$ AlPO- 18 crystals in this sample.

Temperature-Programmed Reduction and Oxidation Studies. Reduction (TPR) and oxidation (TPO) rates were measured on MeAPO samples $(0.1-0.2 \mathrm{~g})$ held within a quartz cell. Temperatures were monitored with K-type thermocouples and set using a Watlow controller (Series 982) and a resistively heated furnace. Reactant mixtures were $1 \% \mathrm{H}_{2} / \mathrm{Ar}$ (Praxair), $20 \% \mathrm{H}_{2} / \mathrm{Ar}$ (Matheson), 1\% CO/He (Praxair), and several mixtures of $\mathrm{O}_{2}$ (Airgas, UHP) in He (Airgas, UHP). Each stream was individually purified using a $13 \mathrm{X}$ molecular sieve at ambient temperature to remove $\mathrm{H}_{2} \mathrm{O}$ and hydrocarbon traces. The effluent was analyzed using a differentially pumped mass spectrometer (MKS Instruments, Orion Compact Residual Gas Analyzer) as the sample temperature was linearly increased while flowing $\mathrm{H}_{2}, \mathrm{CO}, \mathrm{O}_{2}$, or He. $\mathrm{H}_{2}$ (2 amu), He (4 amu), $\mathrm{H}_{2} \mathrm{O}$ (18 amu), $\mathrm{CO}$ (28 amu), $\mathrm{O}_{2}$ (32 amu), Ar (36 and $\left.40 \mathrm{amu}\right)$, and $\mathrm{CO}_{2}(44$ $\mathrm{amu})$ concentrations were measured at $10 \mathrm{~s}$ intervals.

Before $\mathrm{H}_{2}$ or $\mathrm{CO}$ reduction experiments, samples were treated within the cell using the protocol described above (except $20 \%$
$\mathrm{O}_{2} / \mathrm{He}$ was used instead of air) and then cooled to ambient temperature. The $\mathrm{O}_{2}$ stream was replaced with $\mathrm{He}\left(8.33 \mathrm{~cm}^{3}\right.$ $\mathrm{s}^{-1} \mathrm{~g}^{-1}$ ) in order to remove residual gas phase or physisorbed $\mathrm{O}_{2}$. Helium was then replaced with $1 \% \mathrm{H}_{2} / \mathrm{Ar}$ at $3.33 \mathrm{~cm}^{3} \mathrm{~s}^{-1}$ $\mathrm{g}^{-1}$ in $\mathrm{H}_{2}$-TPR studies. After the intensity at 2 amu reached a constant value, the temperature was increased to its final value $(773,823$, or $873 \mathrm{~K})$ at $0.167 \mathrm{~K} \mathrm{~s}^{-1}$. In CO-TPR, He was replaced with $1 \% \mathrm{CO} / \mathrm{He}$ at $3.33 \mathrm{~cm}^{3} \mathrm{~s}^{-1} \mathrm{~g}^{-1}$ and the sample heated to $773 \mathrm{~K}$ at $0.167 \mathrm{~K} \mathrm{~s}^{-1}$. Detailed $\mathrm{H}_{2}$ reduction rates were carried out in a $3.33 \mathrm{~cm}^{3} \mathrm{~s}^{-1} \mathrm{~g}^{-1} 20 \% \mathrm{H}_{2} / \mathrm{Ar}$ stream and measured with a modified Quantasorb apparatus (Quantachrome) equipped with a thermal conductivity detector (TCD). The response was calibrated using known amounts of $\mathrm{CuO}$.

$\mathrm{O}_{2}$-TPO and He-TPD studies were carried out by cooling samples in $1 \% \mathrm{H}_{2} / \mathrm{Ar}$ to ambient temperature after $\mathrm{H}_{2}$-TPR and using $\mathrm{He}\left(8.33 \mathrm{~cm}^{3} \mathrm{~s}^{-1} \mathrm{~g}^{-1}\right)$ to remove residual gas-phase $\mathrm{H}_{2}$ or adsorbed species. The sample temperature was then increased to $773 \mathrm{~K}$ at $0.167 \mathrm{~K} \mathrm{~s}^{-1}$, while $\mathrm{He}$ was used as the carrier gas (He-TPD). For $\mathrm{O}_{2}$-TPO, $\mathrm{He}$ was replaced with $80 \% \mathrm{O}_{2} / \mathrm{He}(8.33$ $\mathrm{cm}^{3} \mathrm{~s}^{-1} \mathrm{~g}^{-1}$ ) and the temperature increased at $0.167 \mathrm{~K} \mathrm{~s}^{-1}$ to $773 \mathrm{~K}$ after the $\mathrm{O}_{2}$ intensity at 32 amu reached constant values. Another $\mathrm{H}_{2}$-TPR $\left(\mathrm{H}_{2}\right.$-TPR-2) measurement was carried out after $\mathrm{O}_{2}$-TPO to probe the reversibility of oxidation-reduction cycles. These experiments were carried out by cooling samples to ambient temperature after $\mathrm{O}_{2}$-TPO, replacing the $\mathrm{O}_{2}$ gas with $\mathrm{He}$ and then with $1 \% \mathrm{H}_{2} / \mathrm{Ar}$, and finally increasing the temperature as in $\mathrm{H}_{2}$-TPR experiments.

In Situ UV - Visible Spectroscopy. UV-visible spectra were measured using a Cary 400 Bio spectrophotometer (Varian Corp.) and an in situ flow cell (Harrick, Inc.) with a diffuse reflectance accessory. $\mathrm{MgO}$ powders treated in $\mathrm{He}$ for $1 \mathrm{~h}$ at $393 \mathrm{~K}$ (Airgas, UHP, dried on 13X molecular sieve) were used as reference. Reflectance $(R)$ data were converted to pseudoabsorbance $(\mathrm{F}(\mathrm{R}))$ using the Kubelka-Munk formalism: ${ }^{14}$

$$
F(R)=(1-R)^{2} / 2 R
$$

Except where noted otherwise, the spectra were measured at ambient temperature between 12000 and $45000 \mathrm{~cm}^{-1}$. Fresh and air-treated samples were exposed to He flow (Airgas, UHP, purified by $13 \mathrm{X}$ sieve) at $393 \mathrm{~K}$ for $1 \mathrm{~h}$ to remove weakly adsorbed species. The effect of $\mathrm{H}_{2}$ treatment was probed by collecting spectra after exposure to $\mathrm{H}_{2}\left(3.33 \mathrm{~cm}^{3} \mathrm{~s}^{-1} \mathrm{~g}^{-1}\right.$, Airgas, UHP, purified by $13 \mathrm{X}$ sieve) at $773 \mathrm{~K}$ for $1 \mathrm{~h}$. Spectra were also collected during temperature-programmed reduction in 3.33 $\mathrm{cm}^{3} \mathrm{~s}^{-1} \mathrm{~g}^{-1} 12.5 \% \mathrm{H}_{2} / \mathrm{He}$ (mixture of the above $\mathrm{H}_{2}$ and $\mathrm{He}$ gases) as the temperature was raised to $773 \mathrm{~K}$ at $0.167 \mathrm{~K} \mathrm{~s}^{-1}$ after samples were treated in air at $773 \mathrm{~K}$ for $1 \mathrm{~h}\left(3.33 \mathrm{~cm}^{3} \mathrm{~s}^{-1}\right.$ $\mathrm{g}^{-1}$, Airgas, zero grade, purified by $13 \mathrm{X}$ sieve). During in situ $\mathrm{H}_{2}$-TPR measurements, UV - visible spectra were acquired at $180 \mathrm{~s}$ intervals in the $12000-27000 \mathrm{~cm}^{-1}$ spectral range. These data are reported as the ratio of the intensity for one of the characteristic features at each condition divided by its initial intensity as a function of treatment temperature. These data are also compared to the cumulative consumption of $\mathrm{H}_{2}$ measured during equivalent $\mathrm{H}_{2}$-TPR experiments.

In Situ X-ray Absorption Spectroscopy. X-ray absorption (XAS) spectra of CoAPO-18 were measured using beamline 4-1 at the Stanford Synchrotron Radiation Laboratory (SSRL) with a storage ring operating at $30-100 \mathrm{~mA}$ and $3.0 \mathrm{GeV}$. The two-crystal $\mathrm{Si}(111)$ monochromator was detuned by $30 \%$ in order to minimize harmonics. The definition slit had vertical and horizontal apertures of 0.2 and $15 \mathrm{~mm}$, respectively, leading to a maximum energy resolution of $1 \mathrm{eV}$ at the Co K edge (7709 $\mathrm{eV}$ ). Ion chambers filled with $\mathrm{N}_{2}$ were used to detect the 
intensities of the incident beam $\left(I_{0}\right)$, the beam after the sample $\left(I_{1}\right)$, and the beam after a reference Co foil located after the sample $\left(I_{2}\right)$. During temperature-programmed experiments, dynamic XANES spectra were acquired in $10 \mathrm{eV}$ increments for $7600-7700 \mathrm{eV}, 0.25 \mathrm{eV}$ for $7700-7725 \mathrm{eV}, 0.5 \mathrm{eV}$ for $7725-7750 \mathrm{eV}, 2 \mathrm{eV}$ for $7750-7790 \mathrm{eV}, 8 \mathrm{eV}$ for $7790-7950$ $\mathrm{eV}$, and $20 \mathrm{eV}$ for $7950-8050 \mathrm{eV}$. Absorption intensities were integrated for $0.5 \mathrm{~s}$ at each energy to give an acquisition time of $270 \mathrm{~s}$ per spectrum.

Samples (10 mg, 125-250 $\mu \mathrm{m}$ pellets) were held within a quartz capillary $(0.8 \mathrm{~mm}$ inner diameter, $0.1 \mathrm{~mm}$ wall thickness). ${ }^{15,16}$ Samples previously treated in air were contacted again with air (Airgas, UHP; $3.33 \mathrm{~cm}^{3} \mathrm{~s}^{-1} \mathrm{~g}^{-1}$ ) as the temperature was increased from ambient to $773 \mathrm{~K}$ at $0.167 \mathrm{~K} \mathrm{~s}^{-1}$ and held at $773 \mathrm{~K}$ for $1 \mathrm{~h}$. Samples were then cooled to ambient temperature, and the air stream was replaced by $\mathrm{He}\left(3.33 \mathrm{~cm}^{3}\right.$ $\mathrm{s}^{-1} \mathrm{~g}^{-1}$ ) for $0.5 \mathrm{~h}$. After replacing $\mathrm{He}$ with $20 \% \mathrm{H}_{2} / \mathrm{Ar}$ (Matheson; $3.33 \mathrm{~cm}^{3} \mathrm{~s}^{-1} \mathrm{~g}^{-1}$ ), X-ray absorption spectra were acquired during $\mathrm{H}_{2}$-TPR experiments, where the sample temperature was increased to $773 \mathrm{~K}$ at $0.067 \mathrm{~K} \mathrm{~s}^{-1}$. MnAPO samples could not be analyzed in situ because $\mathrm{Si}$ atoms in the capillary quartz wall absorb a significant fraction of incident $\mathrm{X}$-rays at the Mn K edge (6539 eV).

Analysis of Near-Edge X-ray Absorption Spectra (XANES). Near-edge and fine structure data were analyzed using WinXAS version $2.1 .^{17,18}$ The energy scale was calibrated by placing the first inflection point in the reference Co foil spectrum at the known Co K edge (7709 eV). A linear regression fit to the preedge region between 7600 and $7680 \mathrm{eV}$ was subtracted from each spectrum, which was then normalized using a third-order polynomial fit for the energy region after the edge (7800-8050 $\mathrm{eV}$ ). Principal component analysis (PCA) ${ }^{19}$ and linear combination methods ${ }^{20}$ were used to obtain the number and concentration of each structurally distinct Co species contributing to the 7700$7770 \mathrm{eV}$ energy region for each spectrum.

Cyclohexane Oxidation on Mn- and CoAPO-5 Materials. Cyclohexane oxidation was carried out in a shielded highpressure glass reactor (Andrews Glass; $100 \mathrm{~cm}^{3}$ ). Cyclohexane ( $25 \mathrm{~cm}^{3}$; Aldrich, 99.99\%) was added together with $\sim 0.2 \mathrm{~g}$ of catalyst; the catalyst was transferred into this reactor immediately after treatment in air at $773-823 \mathrm{~K}$ for $3 \mathrm{~h}$ (see Synthesis and Characterization of MeAPO Samples) with minimal intervening exposure to ambient air. The reactor pressure was raised to $0.4 \mathrm{MPa}$ using pure $\mathrm{O}_{2}$ (Airgas, UHP) while held at ambient temperature before heating to $403 \mathrm{~K}$. Cyclohexanone, cyclohexanol, and cyclohexyl-hydroperoxide products and unreacted cyclohexane were analyzed by gas chromatography (Hewlett-Packard 5890) using a DB-wax column $(30 \mathrm{~m}$ length, $0.32 \mathrm{~mm}$ diameter and $0.5 \mu \mathrm{m}$ film thickness) and a flame ionization detector. The cyclohexyl hydroperoxide response was calibrated using parallel iodometric titrations of liquid samples extracted from the reactor.

\section{Results and Discussion}

Chemical and Structural Changes in Mn- and CoAPO Materials During $\mathbf{H}_{2}$ Treatment. Reduction of cations in $\mathrm{H}_{2}$ can occur via either $\mathrm{O}$-atom removal as $\mathrm{H}_{2} \mathrm{O}$ or via the formation of protons; both processes consume $\mathrm{H}_{2}$, but only the first one forms $\mathrm{H}_{2} \mathrm{O}$. Thus, the amounts of $\mathrm{H}_{2} \mathrm{O}$ evolved and $\mathrm{H}_{2}$ consumed during treatment in $\mathrm{H}_{2}$ can be used to measure the number and type of reducible cations, including details about the amount of removable lattice oxygens. ${ }^{9}$ Typical $\mathrm{H}_{2}-\mathrm{TPR}$ kinetic data are shown in Figure 1. On MnAPO samples, a $\mathrm{H}_{2}$ consumption peak appeared at $\sim 580-600 \mathrm{~K}$; Co cations

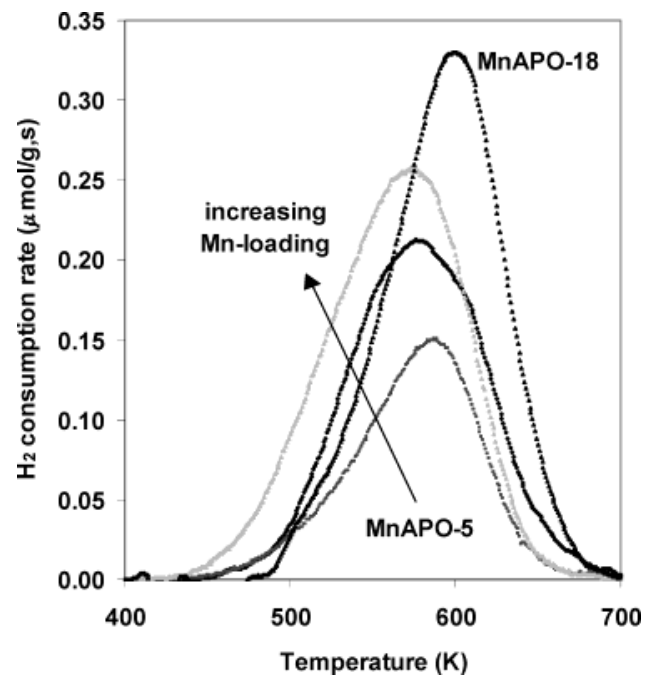

Figure 1. Temperature-programmed reduction of MnAPO-5-1, MnAPO-5-2, MnAPO-5-3, and MnAPO- 18 in 20\% $\mathrm{H}_{2} / \mathrm{Ar}$ [20\% $\mathrm{H}_{2} /$ Ar, $0.167 \mathrm{~K} \mathrm{~s}^{-1}$ from 298 to $773 \mathrm{~K}$, hold $0.5 \mathrm{~h}$ at $773 \mathrm{~K}$ ].

reduced at higher temperatures $(\sim 750 \mathrm{~K}) . \mathrm{H}_{2} \mathrm{O}$ was not detected concurrently with $\mathrm{H}_{2}$ consumption in any of the samples, but small amounts of water appeared at higher temperatures, apparently from condensation of vicinal $\mathrm{OH}$ groups at reduced cations to form extraframework cations or distorted cations within the framework. ${ }^{21,22}$ The absence of $\mathrm{H}_{2} \mathrm{O}$ during $\mathrm{H}_{2}$ consumption indicates that reduction occurs exclusively via formation of protons at cation sites (reaction 1) and that O-atom

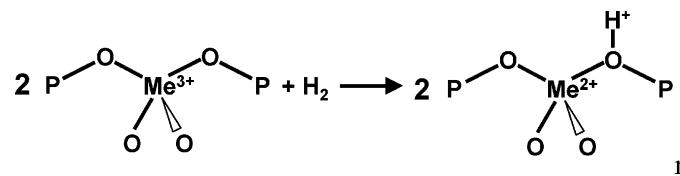

reaction 1

removal occurs at higher temperatures, if at all. Also, the absence of $\mathrm{H}_{2} \mathrm{O}$ confirms the absence of bulk $\mathrm{Mn}$ or Co oxides, which reduce to $\mathrm{MnO}$ or $\mathrm{Co}^{0}$ below $773 \mathrm{~K}$ with the concurrent removal of lattice oxygens and formation of $\mathrm{H}_{2} \mathrm{O}$. The amount of $\mathrm{H}_{2}$ consumed reflects the one-electron reduction of $\mathrm{Me}^{3+}$ to $\mathrm{Me}^{2+}$ shown in reaction 1 , as suggested previously from X-ray absorption $^{22}$ as well as infrared and UV-visible ${ }^{23-25}$ spectra. $\mathrm{H}_{2} / \mathrm{Me}$ consumption ratios $(0.20-0.43$; Table 2$)$ were significantly lower than the value of 0.5 expected from a one-electron reduction of each $\mathrm{Mn}$ or Co cation in these samples. Only some of these cations undergo reduction during $\mathrm{H}_{2}$ treatment up to $773 \mathrm{~K}$; thus, all samples appear to contain a mixture of redoxactive $(40-86 \%)$ and unreactive $(14-60 \%)$ cations.

Previous $\mathrm{H}_{2}$-TPR measurements on CoAPO materials ${ }^{8,26-28}$ have led to $\mathrm{H}_{2} / \mathrm{Co}$ consumption ratios of 0.03 for CoAPO- $5,{ }^{26}$ 0.10 and 0.12 for two different CoAPO-44 samples, ${ }^{26}$ and 0.385 for CoAPO-11.27 The amounts of $\mathrm{H}_{2} \mathrm{O}$ formed were not measured, making it difficult to confirm the exclusive presence of cations at framework positions in these samples. One of these studies proposed that the reduced species resided at extraframework positions and resembled Co oxides, ${ }^{26}$ a proposal inconsistent with the absence of $\mathrm{H}_{2} \mathrm{O}$ evolution during reduction reported here.

Reversibility of Reduction-Oxidation Cycles. The reversibility of reduction events detected during thermal treatment in $\mathrm{H}_{2}$ was probed by attempting the removal of adsorbed $\mathrm{H}$ atoms during heating in $\mathrm{He}(\mathrm{He}-\mathrm{TPD})$ after $\mathrm{H}_{2}$ treatments. The removal of $\mathrm{H}$ atoms formed during reduction by reaction with $\mathrm{O}_{2}$ to form $\mathrm{H}_{2} \mathrm{O}$ was also explored $\left(\mathrm{O}_{2}\right.$-TPO). 
TABLE 2: Chemical Characterization of MeAPO Materials Using Temperature-Programmed $\mathrm{H}_{2}$ or $\mathrm{O}_{2}$ Treatments

\begin{tabular}{lcccccc}
\hline \multicolumn{1}{c}{ sample } & $T_{\max }{ }^{a}(\mathrm{~K})$ & $\mathrm{H}_{2}-\mathrm{TPR}-1^{b}\left(\mathrm{H}_{2} / \mathrm{Me}\right)$ & $\mathrm{O}_{2}-\mathrm{TPO}^{c}\left(\mathrm{H}_{2} \mathrm{O} / \mathrm{Me}\right)$ & $\mathrm{H}_{2}-\mathrm{TPR}-2^{d}\left(\mathrm{H}_{2} / \mathrm{Me}\right)$ & $\mathrm{H}_{2}-\mathrm{TPR}^{-\mathrm{T}^{e}}\left(\mathrm{H}_{2} / \mathrm{Me}\right)$ & $\mathrm{redox}$ fraction \\
\hline MnAPO-18 & 773 & 0.43 & 0.42 & 0.42 & 0.44 & 0.86 \\
MnAPO-18 & 873 & 0.43 & 0.39 & 0.36 & 0.33 & 0.31 \\
MnAPO-5-1 & 773 & 0.31 & & & 0.34 & 0.20 \\
MnAPO-5-2 & 773 & & & & 0.62 \\
MnAPO-5-3 & 773 & 0.32 & 0.30 & 0.31 & 0.40 \\
CoAPO-18 & 823 & 0.20 & & 0.23 & 0.21 & 0.64 \\
CoAPO-5 & 823 & & & & & 0.40
\end{tabular}

${ }^{a}$ Maximum temperature used during treatment. ${ }^{b} \mathrm{H}_{2}$-TPR from 298 to $T_{\max }$ at $0.167 \mathrm{~K} \mathrm{~s}^{-1}\left[0.2 \mathrm{~g}, 25 \mathrm{~cm}^{3} / \mathrm{min} 1 \% \mathrm{H}_{2} / \mathrm{Ar}\right.$, mass spectrometry]. ${ }^{c} \mathrm{O}_{2}$-TPO after $\mathrm{H}_{2}$-TPR from 298 to $T_{\max }$ at $0.167 \mathrm{~K} \mathrm{~s}^{-1}\left[0.2 \mathrm{~g}, 50 \mathrm{~cm}^{3} / \mathrm{min} 80 \% \mathrm{O}_{2} / \mathrm{He}\right.$, mass spectrometry]. ${ }^{d} \mathrm{H}_{2}$-TPR after $\mathrm{O}_{2}$-TPO from 298 to

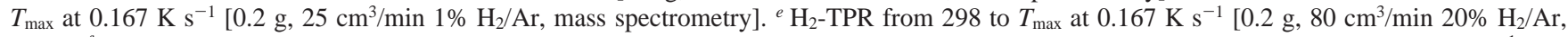
TCD]. ${ }^{f}$ Fraction of metal sites that undergo redox cycles. Calculated from the experimental $\mathrm{H}_{2} / \mathrm{Me}$ ratio and the reaction stoichiometry of $1 /{ }_{2} \mathrm{H}_{2} /$ $\mathrm{Me}_{\text {redox }}$.

$\mathrm{H}_{2}$ evolution was not detected $\left(\mathrm{H}_{2} / \mathrm{Me}<0.01\right)$ during $\mathrm{He}-$ TPD of samples previously reduced during $\mathrm{H}_{2}$-TPR and cooled in $\mathrm{H}_{2}$ to ambient temperature, indicating that the microscopic reverse of proton formation during reduction is not kinetically possible; however, $\mathrm{H}_{2} \mathrm{O}$ desorbs at temperatures above $773 \mathrm{~K}$ indicating the possible recombination of $\mathrm{OH}$ groups. In contrast with $\mathrm{He}, \mathrm{O}_{2}$ removes as $\mathrm{H}_{2} \mathrm{O}$ all of the $\mathrm{H}$ atoms introduced during reduction (reaction 2 ) and leads to the reoxidation of each of the cations that reduced during the initial $\mathrm{H}_{2}$-TPR (Figure 2, Table 2).

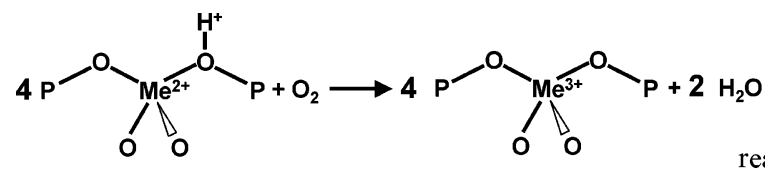

reaction 2

The amount of $\mathrm{H}_{2} \mathrm{O}$ formed during $\mathrm{O}_{2}$-TPO was similar to the $\mathrm{H}_{2}$ consumed during $\mathrm{H}_{2}$-TPR (e.g., $0.42 \mathrm{H}_{2} \mathrm{O} / \mathrm{Mn}$ vs 0.43 $\mathrm{H}_{2} / \mathrm{Mn}$ for MnAPO-18), indicating that $\mathrm{H}_{2}-\mathrm{O}_{2}$ redox cycles are fully reversible. Also, a second $\mathrm{H}_{2}$-TPR gave essentially the same $\mathrm{H}_{2} / \mathrm{Me}$ ratio as the initial $\mathrm{H}_{2}$-TPR (0.42 vs $0.43 \mathrm{H}_{2} /$ $\mathrm{Mn}$ ), confirming that these redox cycles are reversible. These conclusions remain valid for thermal treatment temperatures below $\sim 800 \mathrm{~K}$. When $\mathrm{H}_{2}$-TPR was carried out to $873 \mathrm{~K}$, substantial amounts of $\mathrm{H}_{2} \mathrm{O}$ were evolved, apparently via migration and condensation of $\mathrm{OH}$ groups to form stable $\mathrm{Me}-$ $\mathrm{O}-\mathrm{Me}$ structures containing divalent $\mathrm{Me}$, which did not oxidize during subsequent treatment in $\mathrm{O}_{2} \cdot{ }^{21} \mathrm{H}_{2}$-TPR and $\mathrm{O}_{2}$-TPO cycles on MnAPO-18 with $873 \mathrm{~K}$ as the final temperature led to a decrease in the consumed $\mathrm{H}_{2} / \mathrm{Mn}$ ratio from 0.43 for the initial $\mathrm{H}_{2}$-TPR to 0.36 for a subsequent one. Although the number of redox sites decreased after the treatment at $873 \mathrm{~K}$, the XRD pattern and the BET surface area did not change, indicating that the AIPO structure remained intact even though redox sites were made inactive by this treatment. The higher temperature at which $\mathrm{H}_{2} \mathrm{O}$ forms on CoAPO-18 $(750 \mathrm{~K})$ relative to MnAPO$18(620 \mathrm{~K})$ during $\mathrm{O}_{2}$-TPO, as well as the higher temperatures required for $\mathrm{H}_{2}$ reduction, indicate that $\mathrm{Mn}$ cations are more reactive in redox cycles with $\mathrm{H}_{2}$ and $\mathrm{O}_{2}$ than Co cations in AlPO structures.

The absence of removable $\mathrm{O}$ atoms in CoAPO and MnAPO samples was confirmed by CO-TPR measurements, during which cation reduction must occur with oxygen removal to form $\mathrm{CO}_{2}{ }^{9,29} \mathrm{MnO}_{x}$ and $\mathrm{CoO}_{x}$ structures (e.g., $\mathrm{MnO}_{2}, \mathrm{Mn}_{2} \mathrm{O}_{3}, \mathrm{Co}_{3} \mathrm{O}_{4}$, and $\mathrm{Co}_{2} \mathrm{O}_{3}$ ) reduce via $\mathrm{O}$-atom removal and lead to $\mathrm{CO}_{2}$ formation during treatment in $\mathrm{CO}$ below $773 \mathrm{~K}$. Neither $\mathrm{CO}_{2}$ formation nor $\mathrm{CO}$ consumption were detected during treatment in $\mathrm{CO}$ at temperatures up to $773 \mathrm{~K}$ for MnAPO-5 and CoAPO-5 $\left(\mathrm{CO}_{x} / \mathrm{Me}<0.01\right)$. These results confirm that $\mathrm{H}_{2}$ reduction involves only proton formation and is consistent with the exclusive presence of redox sites in framework positions,
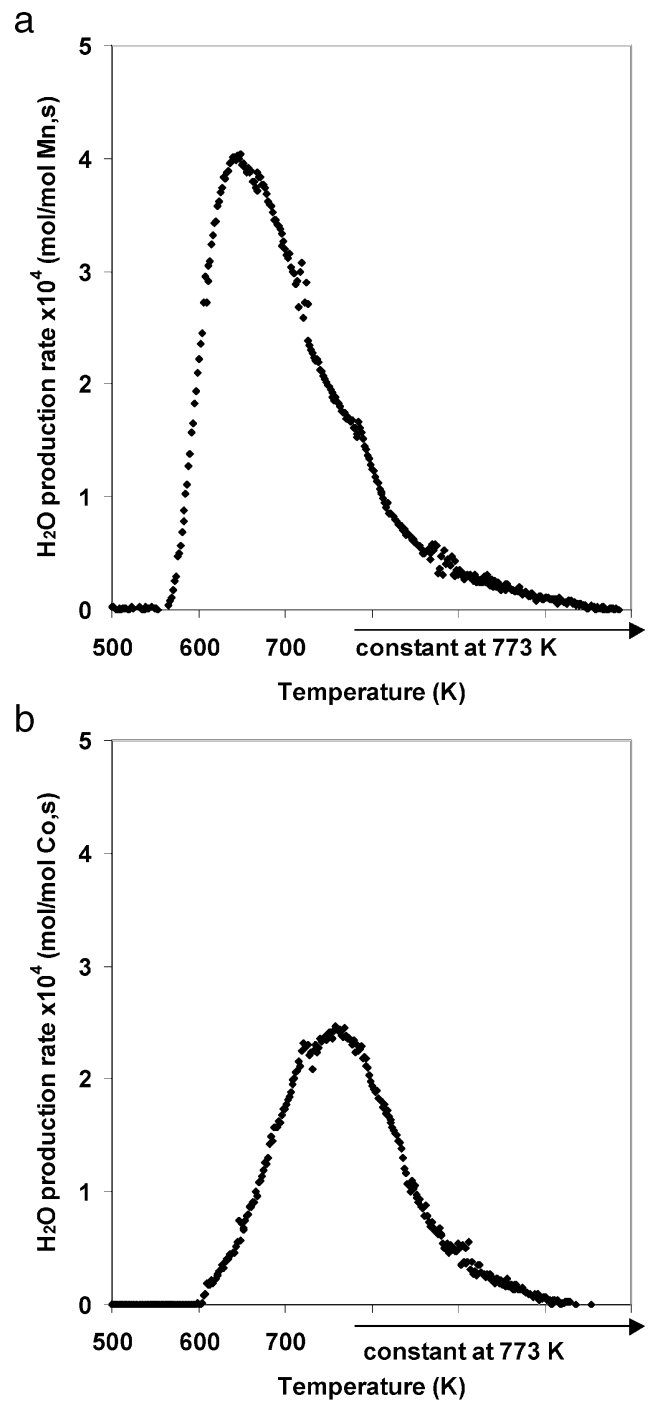

Figure 2. Temperature-programmed oxidation in $80 \% \mathrm{O}_{2} / \mathrm{He}$ of (a) MnAPO-18 and (b) CoAPO-18 [80\% $\mathrm{O}_{2} / \mathrm{He}, 0.167 \mathrm{~K} \mathrm{~s}^{-1}$ from 298 to $773 \mathrm{~K}$, hold $1 \mathrm{~h}$ at $773 \mathrm{~K}$ ].

presumably as isomorphic replacements for Al atoms in AlPO crystalline structures.

An analysis of reduction rates during $\mathrm{H}_{2}$-TPR was used to rigorously assess the relative reduction rates of $\mathrm{Mn}$ and $\mathrm{Co}$ cations in AlPO-5 and AlPO-18 structures. Reduction profiles were described using a rate constant $\left(k=A \mathrm{e}^{-E_{\mathrm{a}} / R T}\right)$ for reaction 1 with a first-order dependence of reduction rates on the residual concentration of oxidized metal centers [ $\left.\mathrm{O}^{*}\right] . \mathrm{H}_{2}$ concentrations changed less than $1 \%$ during reduction and were assumed to remain constant. Any dependence of reduction rates on $\mathrm{H}_{2}$ concentration is contained within the pseudo-first-order preex- 
a

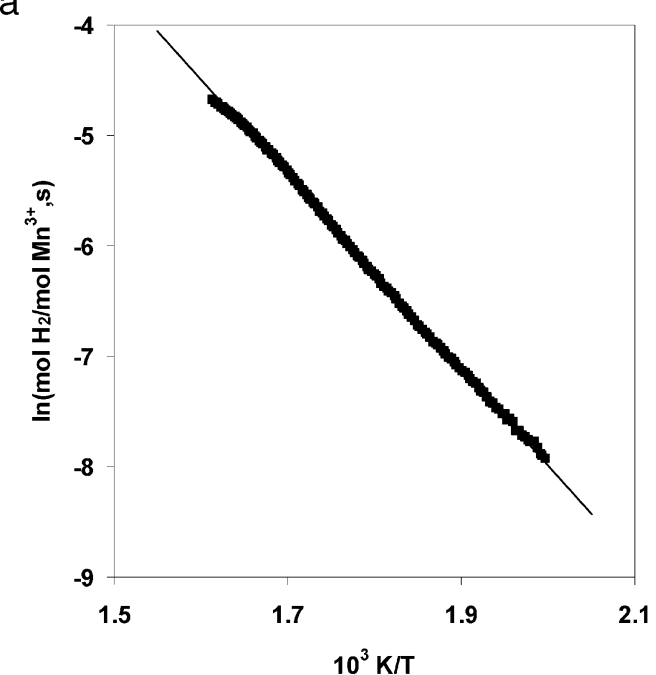

b

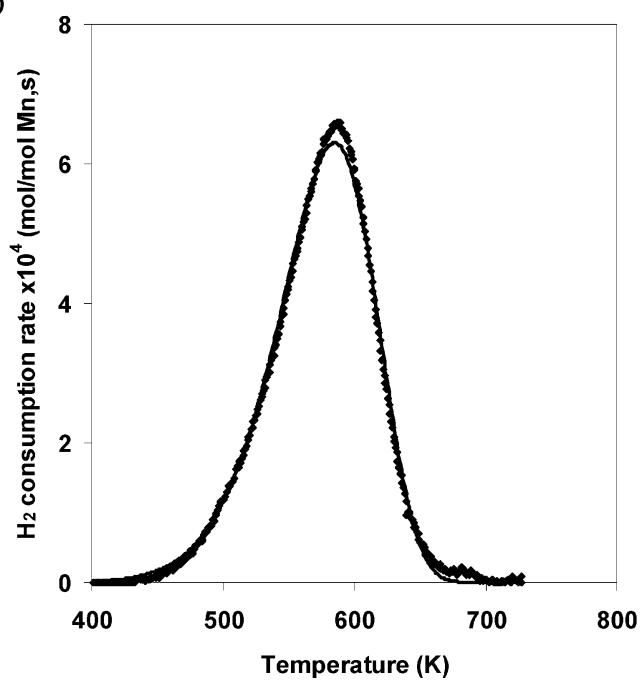

Figure 3. Temperature-programmed reduction of MnAPO-5-2 (a) Arrhenius plot of $\mathrm{H}_{2}$ consumption rate per remaining $\mathrm{Mn}^{3+}$ in the sample (b) experimental (squares) and predicted (solid line) $\mathrm{H}_{2}$ consumption rates $\left[20 \% \mathrm{H}_{2} / \mathrm{Ar}, 0.167 \mathrm{~K} \mathrm{~s}^{-1}\right.$ from 298 to $773 \mathrm{~K}$, hold $0.5 \mathrm{~h}$ at $773 \mathrm{~K}]$.

ponential factor $\left(A_{1}=A\left[\mathrm{H}_{2}\right]^{\alpha}\right)$. Equations $2-4$ provide the basis for $\mathrm{H}_{2}$-TPR data analysis

$r_{\mathrm{H}_{2}}=k\left[\mathrm{H}_{2}\right]^{\alpha}\left[\mathrm{O}^{*}\right]=A \mathrm{e}^{-E_{\mathrm{a}} / R T}\left[\mathrm{H}_{2}\right]^{\alpha}\left[O^{*}\right]=A_{1} \mathrm{e}^{-E_{\mathrm{a}} / R T}\left[O^{*}\right]$

A site balance on oxidized and reduced sites (eq 3) is inserted into eq 2, which is rearranged and shown in Arrhenius-form (eq 4). [L] represents the total concentration of cationic sites that undergo reduction, and $\left[\mathrm{OH}^{*}\right]$ represents the concentration of reduced sites

$$
\begin{gathered}
{[\mathrm{L}]=\left[\mathrm{O}^{*}\right]+\left[\mathrm{OH}^{*}\right] \rightarrow\left[\mathrm{O}^{*}\right]=[\mathrm{L}]-\left[\mathrm{OH}^{*}\right]} \\
\ln \left(\frac{r_{\mathrm{H}_{2}}}{[\mathrm{~L}]-\left[\mathrm{OH}^{*}\right]}\right)=\ln \left(A_{1}\right)-\frac{E_{\mathrm{a}}}{R} \frac{1}{T}
\end{gathered}
$$

The semilogarithmic plot suggested by eq 4 gives a straight line (e.g., Figure 3a for MnAPO-5-2), and Figure 3b demonstrates the excellent agreement between experimental and simulated $\mathrm{H}_{2}$-TPR results. Table 3 shows preexponential factors $\left(A_{1}\right)$ and activation energies $\left(E_{\mathrm{a}}\right)$ for all samples. The data are accurately described using a single kinetic process, which provides additional evidence for the presence of a single type

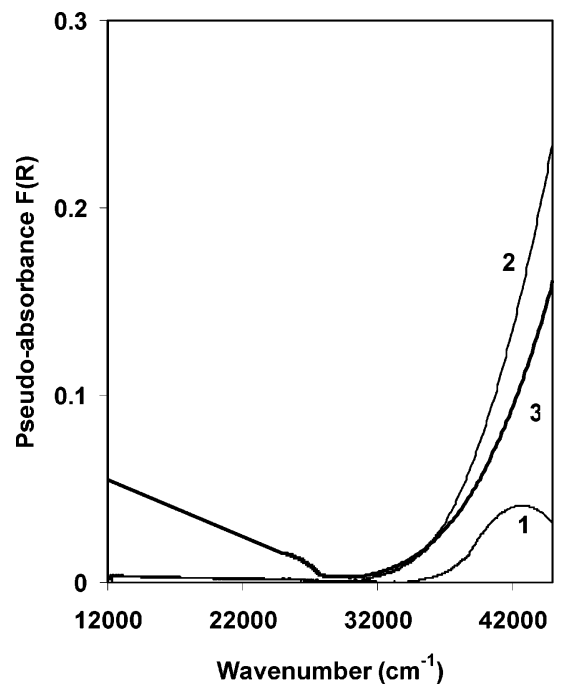

Figure 4. UV-visible spectra of AlPO-18 at 298 K. (1) As prepared, (2) air-treated (air, $0.167 \mathrm{~K} \mathrm{~s}^{-1}$ to $393 \mathrm{~K}, 0.05 \mathrm{~K} \mathrm{~s}^{-1}$ to $823 \mathrm{~K}, 3 \mathrm{~h}$ at $823 \mathrm{~K}$ ), and (3) in situ $\mathrm{H}_{2}$-treated $\left(12.5 \% \mathrm{H}_{2} / \mathrm{He}, 0.167 \mathrm{~K} \mathrm{~s}^{-1}\right.$ to 653 $\mathrm{K}, 1 \mathrm{~h}$ at $653 \mathrm{~K})$.

TABLE 3: Rate Constants and Arrhenius Parameters for $\mathrm{H}_{2}$ Reduction of Mn- and CoAPO Samples [0.2 G, 80 $\mathrm{cm}^{3} / \mathrm{min} 20 \% \mathrm{H}_{2} / \mathrm{Ar}, 0.167 \mathrm{~K} \mathrm{~s}^{-1}$ from 298 to $773 \mathrm{~K}$, Hold $0.5 \mathrm{~h}$ at $773 \mathrm{~K}$ ]

\begin{tabular}{lrcc}
\hline \multicolumn{1}{c}{ sample } & $A_{1}\left(\mathrm{~s}^{-1}\right)$ & $E_{\mathrm{a}}(\mathrm{kJ} / \mathrm{mol})$ & $k($ at $500 \mathrm{~K})\left(\mathrm{s}^{-1}\right)$ \\
\hline MnAPO-5-1 & 22300 & 74.9 & $3.3 \times 10^{-4}$ \\
MnAPO-5-2 & 13200 & 72.6 & $3.4 \times 10^{-4}$ \\
MnAPO-5-3 & 1040 & 59.5 & $6.3 \times 10^{-4}$ \\
MnAPO-18 & 37000 & 79.8 & $1.7 \times 10^{-4}$ \\
CoAPO-5 & 329 & 73.2 & $7.5 \times 10^{-6}$
\end{tabular}

of reducible cations in these samples. A less equivocal conclusion is precluded by the possibility that minority sites catalyze kinetically relevant $\mathrm{H}_{2}$ dissociation steps in a unique kinetic process; the resulting $\mathrm{H}$ atoms could then spill-over and reduce cation sites at rates unaffected by the relative reduction tendencies of a potentially nonuniform distribution of cation structures. Their lower reduction peak temperatures and larger reduction rate constants (Table 3 ) indicate that $\mathrm{Mn}$ cations are more reducible than Co cations in AlPO structures. Reduction rates per $\mathrm{Mn}_{\text {redox }}$ also increased slightly with increasing $\mathrm{Mn} / \mathrm{P}$ ratios in MnAPO-5.

These measurements of the rate and extent of reduction and oxidation in Mn- and CoAPO samples show that these materials contain cations that undergo reversible redox cycles but also cations that do not. The relative amounts of these two cation types can be accurately assessed by these chemical measurements. In parallel, we have probed the structure and electronic properties of Co and Mn sites using UV-visible and X-ray absorption spectroscopies, as described next.

Probing the Redox Behavior of MnAPO and CoAPO Materials Using in Situ UV-Visible Spectroscopy. Figure 4 shows ambient temperature UV-visible spectra for fresh AlPO18 after treatment in $\mathrm{He}$ at $393 \mathrm{~K}$, in dry air at $823 \mathrm{~K}$ for $3 \mathrm{~h}$, and then in $12.5 \% \mathrm{H}_{2} / \mathrm{He}$ at $653 \mathrm{~K}$ for $1 \mathrm{~h}$. The corresponding spectra for MnAPO-18 and MnAPO-5-1 are shown in Figure 5 and those for CoAPO-18 and CoAPO-5 in Figure 6. AlPO18 shows much weaker absorption features in the experimental spectral region $\left(12000-45000 \mathrm{~cm}^{-1}\right)$ than MnAPO-18 or CoAPO-18 after each thermal treatment (Figures 5a and 6a), suggesting that the absorption features in samples containing active cations reflect the electronic spectra of such active Co and Mn cations. The maximum absorption is observed at 41700 

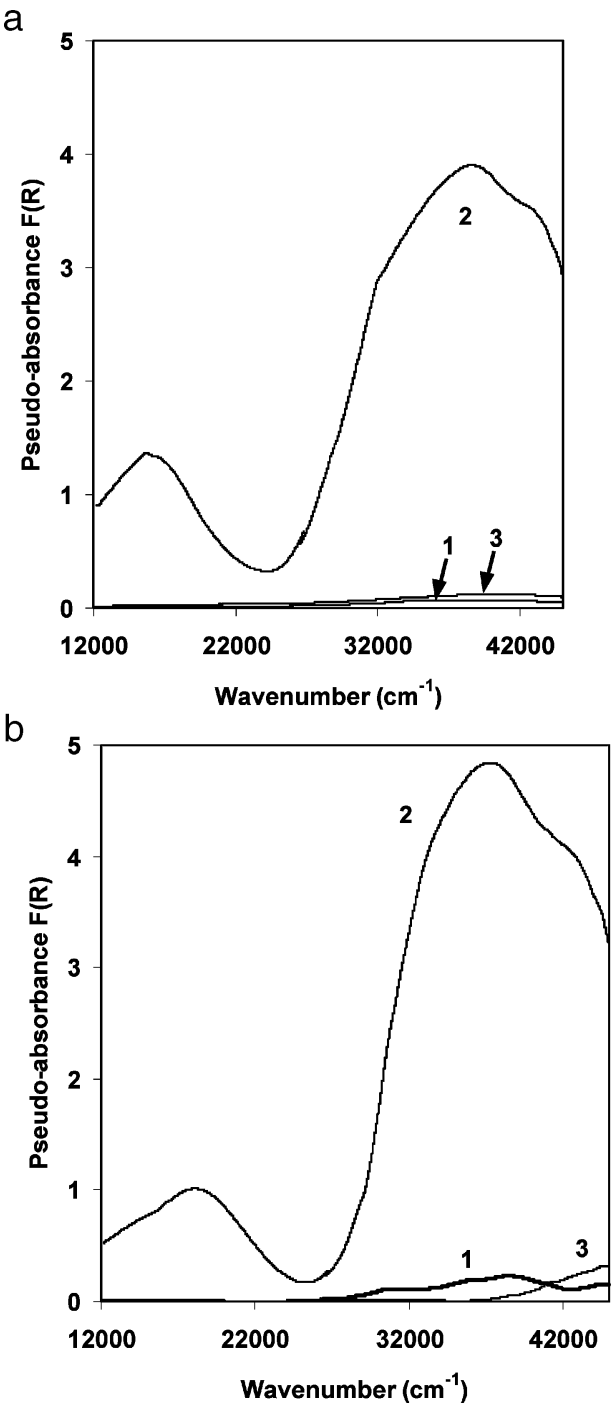

Figure 5. UV-visible spectra at $298 \mathrm{~K}$ of (a) MnAPO-18 and (b) MnAPO-5-1. (1) As prepared, (2) air-treated (air, $0.167 \mathrm{~K} \mathrm{~s}^{-1}$ to 393 $\mathrm{K}, 0.05 \mathrm{~K} \mathrm{~s}^{-1}$ to $823 \mathrm{~K}, 3 \mathrm{~h}$ at $\left.823 \mathrm{~K}\right)$, and (3) in situ $\mathrm{H}_{2}$-treated $(0.167$ $\mathrm{K} \mathrm{s}^{-1}$ to $\left.773 \mathrm{~K}, 12.5 \% \mathrm{H}_{2} / \mathrm{He}\right)$.

$\mathrm{cm}^{-1}$ for the as-synthesized AlPO-18 sample; this maximum shifts to higher wavenumbers (above $45000 \mathrm{~cm}^{-1}$ ) after treatment in air or $12.5 \% \mathrm{H}_{2} / \mathrm{He}$ at $773 \mathrm{~K}$.

The removal of the organic template from fresh MnAPO-18 by treatment in air leads to two intense broad bands (Figures 5a), which are assigned to the oxidation of $\mathrm{Mn}^{2+}$ to $\mathrm{Mn}^{3+}$. The low-energy band $\left(18000 \mathrm{~cm}^{-1}\right)$ corresponds to $\mathrm{d}-\mathrm{d}$ transitions in $\mathrm{Mn}^{3+}$, which has a $\mathrm{d}^{4}$ configuration; $\mathrm{Mn}^{2+}$, with a $\mathrm{d}^{5}$ configuration, does not have an allowed $\mathrm{d}-\mathrm{d}$ transition for highspin configurations, in which each d orbital is occupied by one electron. The high-energy band $\left(37000 \mathrm{~cm}^{-1}\right.$ with $42000 \mathrm{~cm}^{-1}$ shoulder) is attributed to ligand-to-metal charge transfer from the HOMO in $\mathrm{O}$ atoms to the LUMO in $\mathrm{Mn}^{3+}$ cations.

Reported band positions for Mn cations in several valences are reported in Table $4 .^{30}$ Isomorphous substitution of $\mathrm{Mn}$ for $\mathrm{Al}$ in framework positions would lead to tetrahedral coordination. A few cases of tetrahedral $\mathrm{Mn}^{2+}$ compounds have been reported ${ }^{31}$ however, UV-visible spectra for these compounds (or for $\mathrm{Mn}^{3+}$ ) are not available. Thus, the nature of the $\mathrm{Mn}$ environment on MnAPO samples has remained equivocal even after several literature reports. Octahedral $\left[\mathrm{Mn}\left(\mathrm{H}_{2} \mathrm{O}\right)_{6}\right]^{3+}$ shows a single absorption at $21000 \mathrm{~cm}^{-1}$, assigned to ${ }^{5} \mathrm{E}_{\mathrm{g}}-{ }^{5} \mathrm{~T}_{2 \mathrm{~g}} \mathrm{~d}-\mathrm{d}$ transitions. $^{30} \mathrm{Wu}$ et al. reported UV-visible spectra for a

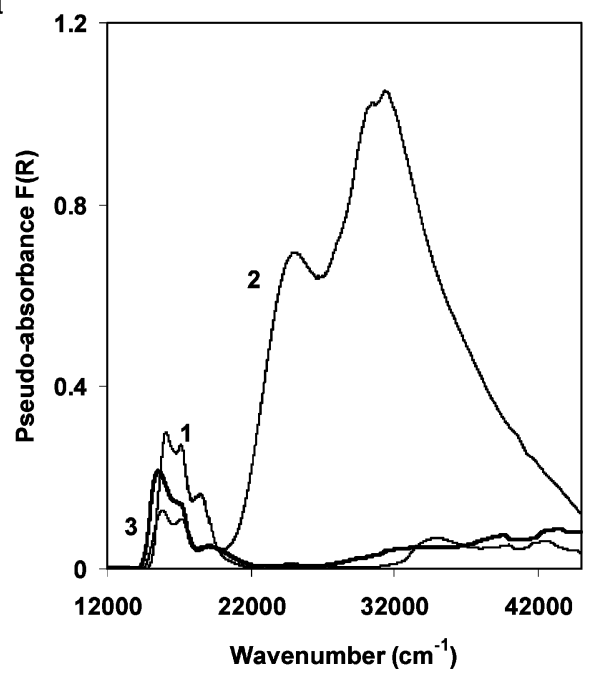

b

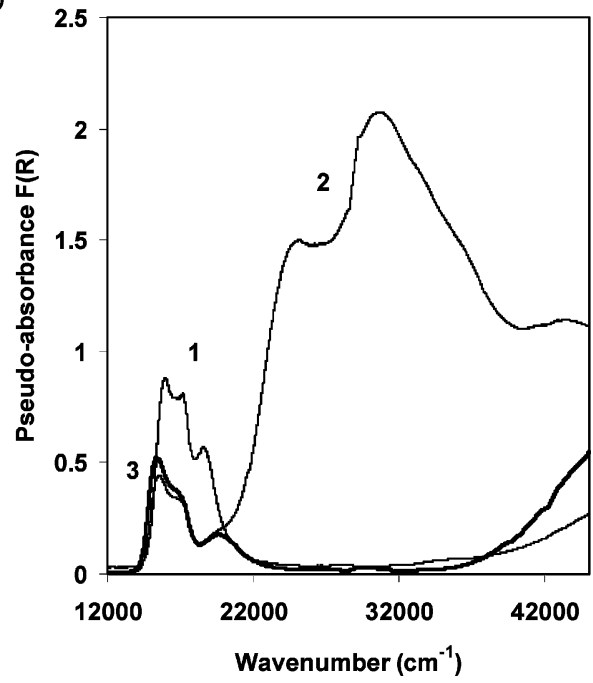

Figure 6. UV-visible spectra at $298 \mathrm{~K}$ of (a) CoAPO-18 and (b) CoAPO-5. (1) As prepared, (2) calcined (823 K, air, $0.167 \mathrm{~K} \mathrm{~s}^{-1}$ to $393 \mathrm{~K}, 0.05 \mathrm{~K} \mathrm{~s}^{-1}$ to $\left.823 \mathrm{~K}, 3 \mathrm{~h}\right)$, and (3) in situ $\mathrm{H}_{2}$-treated $(0.167 \mathrm{~K}$ $\mathrm{s}^{-1}$ to $\left.773 \mathrm{~K}, 12.5 \% \mathrm{H}_{2} / \mathrm{He}\right)$.

TABLE 4: Literature Assignments for Ligand-to-Metal Charge Transfer and d-d Transfer Transitions for Mn Reference Compounds

\begin{tabular}{llll}
\hline \multirow{2}{*}{ compound } & \multicolumn{1}{c}{$\mathrm{Mn}^{n+}$} & \multicolumn{1}{c}{$\begin{array}{c}\text { band position } \\
\left(\mathrm{cm}^{-1}\right)\end{array}$} \\
\hline $\mathrm{MnO}$ & $\mathrm{Mn}^{2+}$ (octahedral) & 23800 & assignment \\
& & 20800 & ${ }^{6} \mathrm{~A}_{1 \mathrm{~g}} \rightarrow{ }^{4} \mathrm{~A}_{1 \mathrm{~g}}$ \\
& & 16400 & ${ }^{6} \mathrm{~A}_{1 \mathrm{~g}} \rightarrow \mathrm{T}_{2 \mathrm{~g}}$ \\
$\mathrm{Mn}_{3} \mathrm{O}_{4}$ & $\mathrm{Mn}^{2+}$ (spinel) & 39125 & ${ }^{6} \mathrm{~A}_{1 \mathrm{~g} \rightarrow} \rightarrow \mathrm{T}_{2 \mathrm{~g}}$ \\
& $\mathrm{Mn}^{3+}$ (spinel) & 31250 & $\mathrm{O}^{2-} \rightarrow \mathrm{Mn}^{2+}$ \\
$\alpha-\mathrm{Mn}_{2} \mathrm{O}_{3}$ & $\mathrm{Mn}^{3+}$ (pseudo-octahedral) & 27027 & $\mathrm{O}^{2-} \rightarrow \mathrm{Mn}^{3+}$ \\
& & 20618 & ${ }^{5} \mathrm{~B}_{1 \mathrm{~g}} \rightarrow{ }^{5} \mathrm{~B}_{2 \mathrm{~g}}$ \\
& & 13245 & ${ }^{5} \mathrm{~B}_{1 \mathrm{~g}} \rightarrow{ }^{5} \mathrm{E}_{\mathrm{g}}$ \\
$\mathrm{Mn}-\mathrm{Al}_{2} \mathrm{O}_{3}$ & $\mathrm{Mn}^{2+}$ & 23696 & ${ }^{5} \mathrm{~B}_{1 \mathrm{~g}} \rightarrow{ }^{5} \mathrm{~A}_{1 \mathrm{~g}}$ \\
& $\mathrm{Mn}^{3+}$ & $18700-20600$ & ${ }^{5} \mathrm{C}_{1 \mathrm{~g}} \rightarrow{ }^{5} \mathrm{E}_{1 \mathrm{~g}} \mathrm{~T}_{2 \mathrm{~g}}$ \\
& $\mathrm{Mn}^{4+}$ & 21300 & ${ }^{4} \mathrm{~A}_{2 \mathrm{~g}} \rightarrow{ }^{4} \mathrm{~T}_{2 \mathrm{~g}}$
\end{tabular}

MnAPO-5 treated in air at $823 \mathrm{~K}$ for $6 \mathrm{~h}$ but then exposed to ambient moisture, which leads to coordination by water and changes in the electronic spectrum of Mn centers. ${ }^{7}$ Nevertheless, their spectra resemble those reported here for samples held within strictly controlled anhydrous environments. Their study reported two ligand-to-metal charge-transfer bands at 45450 and $38760 \mathrm{~cm}^{-1}$ and one $\mathrm{d}-\mathrm{d}$ absorption band at $20000 \mathrm{~cm}^{-1}$.

In contrast with air-treated MnAPO-18, UV-visible spectra for fresh and $\mathrm{H}_{2}$-treated MnAPO-18 resemble those for pure 
a

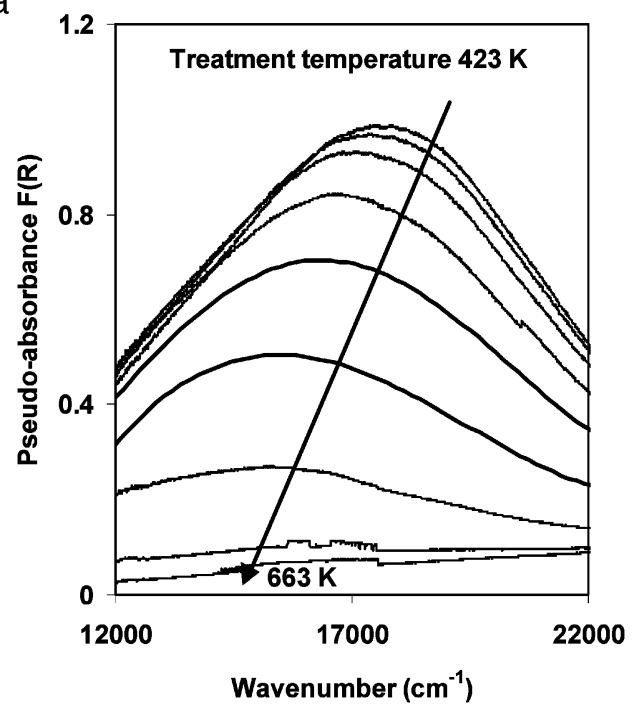

b

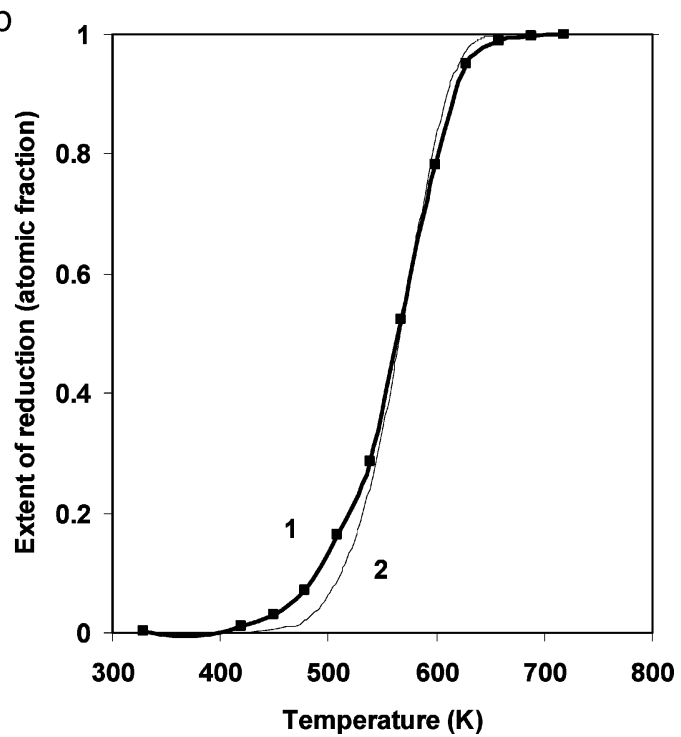

Figure 7. (a) Temperature-programmed reduction of MnAPO-5-1 monitored by UV-visible spectroscopy. (b) Comparison of the extent of reduction of Mn-redox sites detected by (1) UV-visible spectroscopy and (2) $\mathrm{H}_{2}$ consumption measurements.

AlPO-18 (Figures 4 and 5a). This reflects the predominant presence of $\mathrm{Mn}^{2+}$ with a $\mathrm{d}^{5}$ configuration. Octahedral $[\mathrm{Mn}$ $\left.\left(\mathrm{H}_{2} \mathrm{O}\right)_{6}\right]^{2+}$ shows broad absorption bands of very low intensity starting at $18000 \mathrm{~cm}^{-1} .30$ The presence of any $\mathrm{Mn}^{3+}$ species in as-synthesized and $\mathrm{H}_{2}$-treated samples would have led to detectable $\mathrm{d}-\mathrm{d}$ transitions; thus, we conclude that this $\mathrm{H}_{2-}$ treatment reduces all $\mathrm{Mn}^{3+}$ species initially present in the sample to $\mathrm{Mn}^{2+}$

The results of chemical analysis of the effluent during $\mathrm{H}_{2-}$ TPR were compared with the relative amounts of divalent and trivalent cations obtained from UV-visible spectra by carrying out $\mathrm{H}_{2}$-TPR experiments while continuously monitoring UVvisible spectra (e.g., MnAPO-5-1; Figure 7a). The $d-d$ band for $\mathrm{Mn}^{3+}\left(18000 \mathrm{~cm}^{-1}\right)$ was used as reference as the spectrum changed during TPR; using the band at $37000 \mathrm{~cm}^{-1}$ led to identical results, because it decreased to the same extent during reduction and corresponds to the same species. Band intensities for air-treated and $\mathrm{H}_{2}$-treated samples were used to define zero and complete reduction of redox-active cations, respectively, because nonredox sites are not affected and do not contribute to the intensity of absorption features.
TABLE 5: Energies for Absorption Maxima after Various Treatments of CoAPO-5 and CoAPO-18

\begin{tabular}{lcl}
\hline \multirow{2}{*}{\multicolumn{1}{c}{ samples }} & \multicolumn{2}{c}{ wavenumber $\left(\mathrm{cm}^{-1}\right)$} \\
\cline { 2 - 4 } \multicolumn{1}{c}{ visible region } & \multicolumn{1}{c}{ UV region } \\
\hline as prepared CoAPO-18 & $16000,17200,18600$ & none \\
as prepared CoAPO-5 & $15800,17200,18600$ & none \\
calcined CoAPO-18 & $15800,17200,19100$ & 25100,30800 \\
calcined CoAPO-5 & $15600,17200,19400$ & 25000,31100 \\
reduced CoAPO-18 & $15600,17200,19100$ & none \\
reduced CoAPO-5 & $15400,17200,19400$ & none
\end{tabular}

Figure $7 \mathrm{~b}$ shows that chemical analysis and UV-visible assessments of the extent of reduction are in excellent agreement. As mentioned earlier, we note that spectral features for $\mathrm{Mn}^{3+}$ were absent in $\mathrm{UV}-$ visible spectra collected after $\mathrm{H}_{2-}$ TPR to $773 \mathrm{~K}$, indicating that this treatment reduced all $\mathrm{Mn}^{3+}$ cations to $\mathrm{Mn}^{2+}$. Thus, any $\mathrm{Mn}$ cations that do not undergo reduction during this $\mathrm{H}_{2}$ treatment (as shown from the $\mathrm{H}_{2} / \mathrm{Mn}$ ratio below 0.5 ) must have already been in their divalent state before $\mathrm{H}_{2}$ treatment. For example, air-treated MnAPO-5-1 contains $62 \%$ of the $\mathrm{Mn}$ cations as $\mathrm{Mn}^{3+}$, all of which reduce to $\mathrm{Mn}^{2+}$ during $\mathrm{H}_{2}$ treatment at $773 \mathrm{~K}$. The remaining $38 \%$ of the Mn cations must already be present as $\mathrm{Mn}^{2+}$ and they do not reoxidize during subsequent thermal treatment in air up to $823 \mathrm{~K}$. We expect, and indeed find and discuss later, that these permanently divalent cations are not relevant to catalytic oxidation pathways; the structure of these sites and their lack of catalytic implications are discussed in more detail below.

CoAPO-18 and CoAPO-5 showed three overlapping bands at low energies $\left(15000-20000 \mathrm{~cm}^{-1}\right)$ for all treatments, whereas two broad features with maxima at 25000 and 31000 $\mathrm{cm}^{-1}$ appeared only during treatment in air (Figure 6, Table 5). The spectra for fresh, air-treated and $\mathrm{H}_{2}$-treated CoAPO-5 and CoAPO-18 resemble those previously reported for CoAPO- $5^{12,13}$ and CoAPO-18. ${ }^{24,25}$ Low-energy spectral features have been assigned to $\mathrm{Co}^{2+}$, but their sensitivity to coordination symmetry remains unclear, because multiple complex electronic transitions are available in both tetrahedral and octahedral $\mathrm{Co}^{2+} \mathrm{com}-$ plexes. ${ }^{30}$ Tetrahedral $\left[\mathrm{CoCl}_{4}\right]^{2-}$ shows two bands at 5500 and $14700 \mathrm{~cm}^{-1}$, which were assigned to ${ }^{4} \mathrm{~A}_{2} \rightarrow{ }^{4} \mathrm{~T}_{1}(\mathrm{~F})$ and ${ }^{4} \mathrm{~A}_{2} \rightarrow$ ${ }^{4} \mathrm{~T}_{1}(\mathrm{P})$ transitions, respectively. ${ }^{31} \mathrm{~A}$ third transition $\left({ }^{4} \mathrm{~A}_{2} \rightarrow{ }^{4} \mathrm{~T}_{2}\right)$ at $3500 \mathrm{~cm}^{-1}$ is expected, but it is very weak. ${ }^{31} \mathrm{We}$ have assigned the three overlapping bands at $15000-20000 \mathrm{~cm}^{-1}$ to ${ }^{4} \mathrm{~A}_{2} \rightarrow{ }^{4} \mathrm{~T}_{1}(\mathrm{P})$ transitions in tetrahedral $\mathrm{Co}^{2+}$ structures, consistent with Verberckmoes et al., ${ }^{12}$ who detected a band at $5000-9000 \mathrm{~cm}^{-1}$ for CoAPO-5 (cf. $5500 \mathrm{~cm}^{-1}$ for $\left[\mathrm{CoCl}_{4}\right]^{2-}$ ) and assigned it to these transitions. The splitting of bands between 15000 and $20000 \mathrm{~cm}^{-1}$ reflects significant distortion of tetrahedral Co centers, as suggested previously from spectral changes observed during template removal in CoAPO-36 relative to tetrahedral $\left[\mathrm{CoCl}_{4}\right]^{2-}$. The two overlapping bands at higher energies have been assigned to $\mathrm{Co}^{3+},{ }^{22,24,25,32}$ but it is unclear whether they arise from $\mathrm{d}-\mathrm{d}$ or ligand-to-metal transitions. Tetrahedral $\left[\mathrm{Co}^{\mathrm{III}} \mathrm{W}_{12} \mathrm{O}_{40}\right]^{5-}$ gives a single band at 25700 $\mathrm{cm}^{-1}$ due to ${ }^{5} \mathrm{E} \rightarrow{ }^{5} \mathrm{~T}_{2}$ transitions. ${ }^{33}$ The doublet in CoAPO-5 and CoAPO-18 spectra appears to arise, as in $\mathrm{Co}^{2+}$, from distorted tetrahedral symmetry. Verberckmoes et al. detected a feature in the near-infrared $\left(9000 \mathrm{~cm}^{-1}\right)$ for CoAPO-5 treated in air and assigned it to $\mathrm{d}-\mathrm{d}$ transitions, suggesting that the remaining high-energy bands reflect instead ligand-to-metal charge transfer. ${ }^{12}$

As in the case of MnAPO-5, UV-visible spectra of CoAPO-5 during $\mathrm{H}_{2}$ treatment can be compared with $\mathrm{H}_{2}$ consumption rates during $\mathrm{H}_{2}$-TPR (Figure 8). Here, we use the $\mathrm{Co}^{3+}$ band at 25000 $\mathrm{cm}^{-1}$ as reference, but the other absorption band $\left(31000 \mathrm{~cm}^{-1}\right)$ 
a

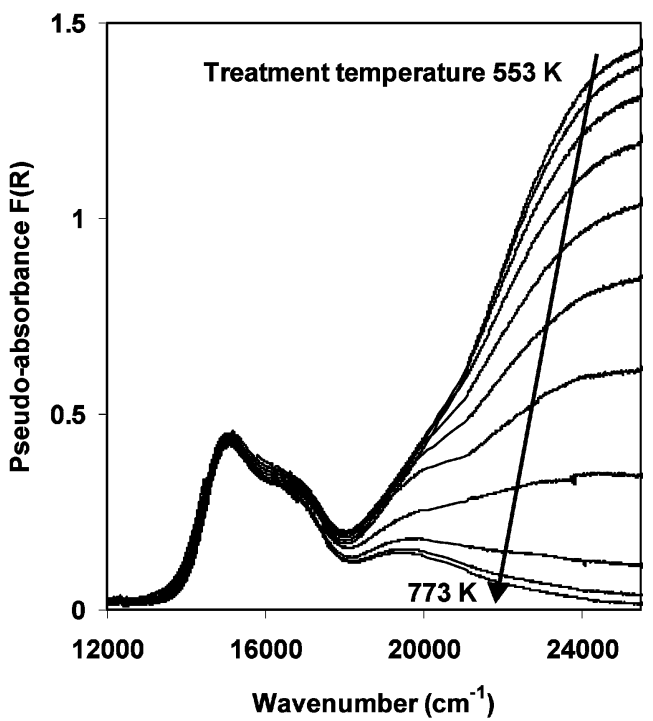

b

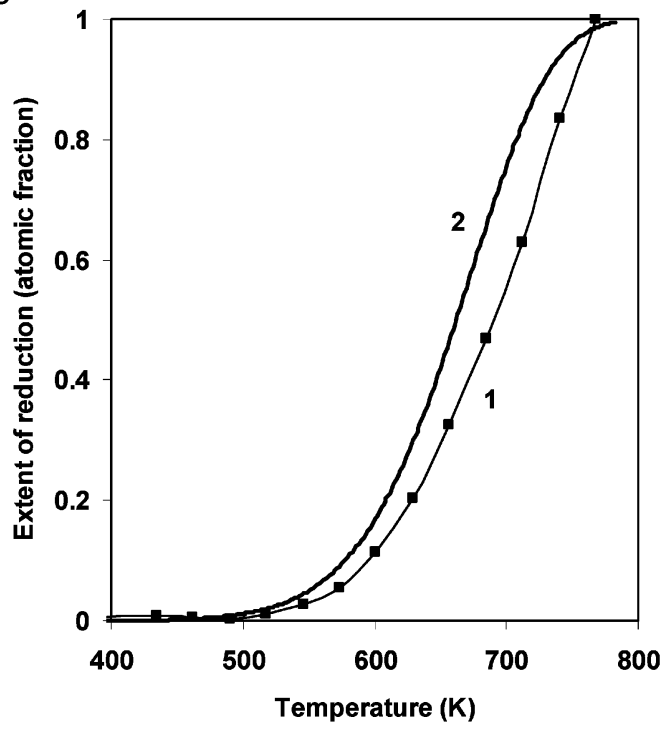

Figure 8. (a) Temperature-programmed reduction of CoAPO-5 monitored by UV-visible spectroscopy. (b) Comparison of the extent of reduction of Co-redox sites detected by (1) UV-visible spectroscopy and (2) $\mathrm{H}_{2}$ consumption measurements.

follows identical trends, indicating that it arises from other transitions in the same Co cation species. The agreement between these two methods is again excellent, indicating also that the assignment of the high-energy band to $\mathrm{Co}^{3+}$ is indeed correct. As for MnAPO-5, we conclude that only some of the Co cations (40\%) in CoAPO-5 undergo redox cycles and that all $\mathrm{Co}$ species are present as $\mathrm{Co}^{2+}$ after treatment in $\mathrm{H}_{2}$ at 773 $\mathrm{K}$. Thus, redox-inactive species are permanently divalent during all thermal treatments.

In addition to confirming the assignment of the high-energy band to $\mathrm{Co}^{3+}$, we also comment on the origins of absorption bands in the low-energy triplet region $\left(15000-20000 \mathrm{~cm}^{-1}\right)$. The integrated intensity in this spectral region decreased by $45 \%$ for CoAlPO-18 (Figure 6a) and 55\% for CoAPO-5 (Figure 6b) after treatment in air at $823 \mathrm{~K}$; this decrease is in quantitative agreement with the results of Peeters et al. (45-55\%) for CoAPO-5 at similar conditions. ${ }^{34}$ The weaker intensity observed after air treatment cannot be recovered after subsequent treatment in $\mathrm{H}_{2}$ at $773 \mathrm{~K}$; thus, some of the $\mathrm{Co}^{2+}$ species initially present cannot be restored to their initial structure by treatment in $\mathrm{H}_{2}$ at $773 \mathrm{~K}$, and only a small intensity increase $(\sim 15 \%)$ was observed, in agreement with previous studies, which provided no interpretation for these results. ${ }^{12,13}$ The partial and irreversible loss of intensity for this triplet band during template removal and during subsequent treatment in $\mathrm{H}_{2}$ does not reflect irreversible redox processes, because chemical characterization shows that redox cycles are fully reversible. These changes reflect instead some structural distortion of $\mathrm{Co}^{2+}$ centers during air treatment. The detailed shape and position of these bands also differ among the various samples (fresh, air-treated, and $\mathrm{H}_{2}$-treated samples); specifically, the bands shift and the splitting increases after air or $\mathrm{H}_{2}$ treatments, indicating additional distortion and a consequent decrease in absorption cross-sections during template removal and high-temperature treatments.

We speculate that structural distortion occurs via recombination of hydroxyls associated with reduced $\mathrm{Co}^{2+}$ sites initially present in the sample after synthesis. This process requires vicinal or at least mobile Co sites in order to form $\mathrm{H}_{2} \mathrm{O}$ and an oxygen vacancy ${ }^{21}$ that must be stabilized by two $\mathrm{Co}^{2+}$ atoms. The mere presence of a vacancy site will cause significant distortion of Co centers from the tetrahedral symmetry required by the AlPO framework; $\mathrm{Co}-\mathrm{O}-\mathrm{Co}$ structures within an AlPO crystalline framework would also lead to significant structural distortion.

The partial recovery of the triplet intensity in CoAPO-5 during the $\mathrm{H}_{2}$-treatment following air-treatment indicates that $\mathrm{Co}$ centers that remain divalent throughout both treatments $(\sim 60 \%)$ account for the triplet intensity. In contrast, the $40 \%$ of the Co species that undergo redox cycles only contribute marginally to the triplet absorption bands after reduction in $\mathrm{H}_{2}$ to $\mathrm{Co}^{2+}$. The fraction of Co in CoAPO-18 that is redox-active (64\%) is larger than in CoAPO-5 (40\%) and the changes in intensity within the $\mathrm{Co}^{2+}$ triplet region are commensurately larger. Changes in extinction coefficients arising from structural distortion and the contributions from redox accessible and inaccessible $\mathrm{Co}^{2+}$ sites make this spectral region ill-suited for quantitative assessments of the Co oxidation state in these samples. We conclude that valence and structural changes combine to give the observed changes in the UV-visible spectra of CoAPO samples during various thermal treatments. Their unequivocal interpretation and quantitative assessment require parallel chemical and spectroscopic studies, as we have carried out and report here.

X-ray Absorption Spectroscopy During Treatment of CoAPO-18 in $\mathbf{H}_{2}$. CoAPO materials have been previously studied using X-ray absorption spectroscopy. ${ }^{5,22,35-38}$ Specifically, the fine structure in the absorption spectrum has been used to measure coordination numbers and bond distances; ${ }^{22}$ recently, Cora et al. extended such methods to MnAPO materials. ${ }^{39}$ These methods use changes in bond distances between freshly prepared and air-treated samples to determine $\mathrm{Mn}$ and Co oxidation states by assuming the exclusive presence of trivalent cations in the samples with shortest $\mathrm{Me}-\mathrm{O}$ bond distances (Co and $\mathrm{Mn}$ in MeAPO-18). This approach assumes a simple (and undemonstrated) linear relation between $\mathrm{M}-\mathrm{O}$ bond distances and cation oxidation states. Despite the nonrigorous nature of this approach, it gave qualitative trends similar to those in our $\mathrm{H}_{2}$-TPR measurements, including a lower fraction of the Co as redox-active species in CoAPO-5 than in CoAPO18. The required assumption that all cations in AlPO-18 are initially their trivalent state, however, is inconsistent with our $\mathrm{H}_{2}$-TPR data, which show that only $86 \%$ and $64 \%$ of cations are trivalent after treatment in air in MnAPO-18 and CoAPO18, respectively. Our UV-visible studies have also shown that misleading conclusions could arise from the comparison of 
a

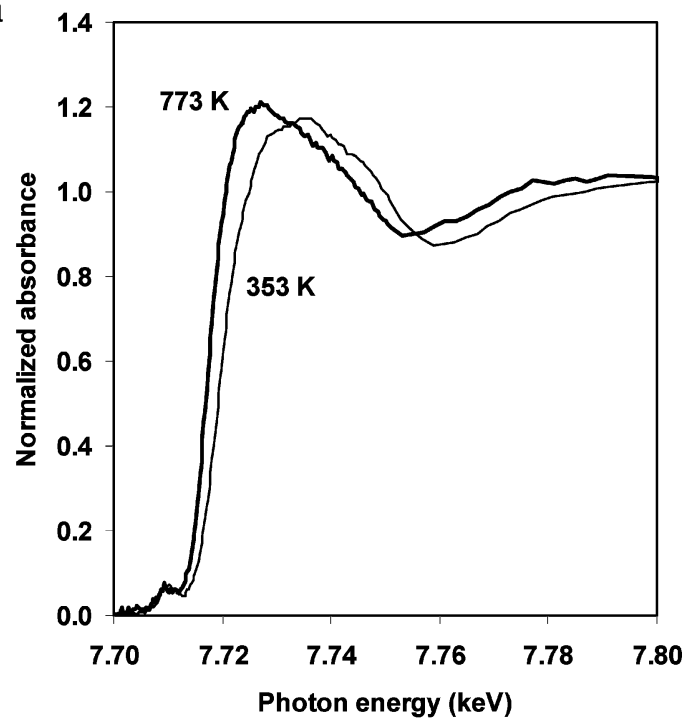

b

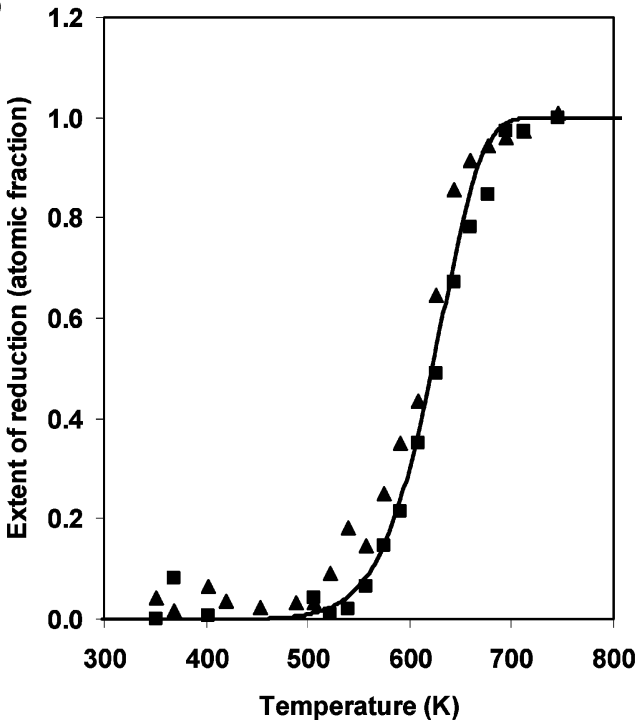

Figure 9. (a) XANES spectra during temperature-programmed reduction in $20 \% \mathrm{H}_{2} / \mathrm{Ar}$ of CoAPO-18 initially treated in air at $823 \mathrm{~K}$. At $353 \mathrm{~K}$, no reduction has been detected, and at $773 \mathrm{~K}$, the reduction is complete. (b) Comparison of the extent of reduction of Co-redox sites detected by X-ray absorption spectroscopy (linear combination, squares, and edge energy, triangles) and $\mathrm{H}_{2}$ consumption measurements (solid line). To calculate the extent of reduction, the intermediate spectra during the reduction were fit with a linear combination of the oxidized $(353 \mathrm{~K})$ and the reduced $(773 \mathrm{~K})$ spectra.

spectral features of as synthesized and subsequent samples. Indeed, $\mathrm{Me}-\mathrm{O}$ bond distances are not completely restored to their initial values during subsequent reduction in $\mathrm{H}_{2}$, so relevant comparisons should be made between air-treated and $\mathrm{H}_{2}$-treated rather than using as synthesized materials, which still contain the template, as standards for divalent cations. ${ }^{22}$ Finally, the presence of at least two types of metal cations (redox-active and permanently divalent) requires rigorous multiple-shell scattering simulations for analyzing the details of the fine structure; these were carried out only for CoAPO-18 in previous studies. ${ }^{22}$

Here, we use the near-edge region, instead of the fine structure, of X-ray absorption spectra to probe changes in oxidation state and coordination symmetry during thermal treatments, and we combine these measurements with $\mathrm{H}_{2}$-TPR data obtained at identical conditions. Near-edge $\mathrm{Co}-\mathrm{K}$ spectra for CoAPO-18 are shown in Figure 9a after treatment in air or $\mathrm{H}_{2}$. They are used as references to define the expected spectra when redox-active sites are fully oxidized and fully reduced, respectively. Principal component analysis of spectral transients collected during $\mathrm{H}_{2}$-TPR showed that only two components were required to describe the evolution of the spectra during these treatments. In view of this, we have used the spectra after air and $\mathrm{H}_{2}$ treatments (Figure 9a) for linear superimposition regressions of the spectral evolution during $\mathrm{H}_{2}$-TPR. The results are shown in Figure $9 \mathrm{~b}$ as the extent of reduction as a function of treatment temperature, along with similar data obtained by chemical analysis of the effluent during $\mathrm{H}_{2}$-TPR. The two methods give very similar extents of reduction.

The edge energy can also be used to estimate the extent of reduction during $\mathrm{H}_{2}$-TPR; this is done by using edge energies for air-treated $(7.7194 \mathrm{keV})$ and $\mathrm{H}_{2}$-treated $(7.7170 \mathrm{keV})$ CoAPO-18 as standards. A linear relation between edge energy and extent of reduction is then used to determine the extent of reduction for the intermediate spectra. As seen in Figure 9b, this method gives a larger signal-to-noise ratio than the linear combination fit, but the results follow the same trend as both the linear combination and the $\mathrm{H}_{2}$ consumption data, indicating the accuracy of this method. The observed decrease in the $\mathrm{Co}-\mathrm{K}$ edge energy $(\sim 2.4 \mathrm{eV})$ with $\mathrm{H}_{2}$ treatment at $773 \mathrm{~K}$ is significantly larger than reported previously for CoAPO-18 (1.2 eV). ${ }^{36}$ This shift in edge energy coincided with the $\mathrm{H}_{2}$ consumption and with the decrease in the intensity of $\mathrm{Co}^{3+} \mathrm{UV}-$ visible bands during $\mathrm{H}_{2}$-TPR. A decrease in edge energy is indeed expected upon reduction, as electrons increasingly fill empty orbitals near the vacuum level. For CoAPO-18 (64\% reduction), the $2.4 \mathrm{eV}$ energy shift corresponds to $3.75 \mathrm{eV} /$ valence. This shift is in agreement with relations between oxidation state and edge energy for $\mathrm{Co}$ and $\mathrm{Mn}$ compounds with known valence and structure $(3.5-4.5 \mathrm{eV} / \mathrm{valence}){ }^{38,40}$

Comments about the Nature of Permanently Divalent Cations in AIPO Materials. Chemical characterization and spectroscopic methods led us to the definite conclusion that all MeAPO samples contain some divalent cations that do not undergo redox cycles during subsequent exposure to $\mathrm{H}_{2}$ or $\mathrm{O}_{2}$ at high temperatures. The absence of redox processes and of removable $\mathrm{O}$ atoms indicates that permanently divalent species are not present as extraframework $\mathrm{Mn}_{x} \mathrm{O}_{y}$ and $\mathrm{Co}_{x} \mathrm{O}_{y}$ clusters, which would undergo redox cycles with $\mathrm{O}$ atom removal at the conditions of our treatments. Inert $\mathrm{Co}$ or $\mathrm{Mn}$ aluminates or phosphates could be present as inert amorphous phases and account for the permanently divalent cations, but we do not detect their crystalline counterparts by X-ray diffraction.

UV-visible spectra showed that irreversible distortion accompanies the formation of permanently divalent sites during initial treatment of template-containing samples in air. This suggests that these sites are likely to form, or at least acquire their structural distortion, during oxidative removal of the organic template. These processes can lead to high local temperatures and to hydrothermal conditions conducive to restructuring of crystalline oxide structures. X-ray absorption spectra, however, detected only a small decrease in $\mathrm{Me}-\mathrm{O}$ bond distances during treatment in air and a small increase during subsequent treatment in $\mathrm{H}_{2}$ at $773 \mathrm{~K},{ }^{22}$ indicating that no significant structural transformations accompany redox cycles. No detectable intensity was observed beyond the first $\mathrm{Co}-\mathrm{O}$ shell in the radial structure function, suggesting the absence of crystalline phases with $\mathrm{Co}-\mathrm{Co}$ next nearest neighbors. This conclusion must be treated with caution, because local static disorder in crystalline oxides can lead to weak intensities beyond $\mathrm{Me}-\mathrm{O}$ bonds in the radial structure functions of materials with $\mathrm{Me}-\mathrm{O}-\mathrm{Me}$ structures. 
Taken together, the structural distortion detected in UVvisible spectra and the minor changes in the X-ray absorption radial structure function ${ }^{22}$ suggest that permanently divalent structures consist of dehydroxylated structures. These structures were first proposed by Peeters et al. ${ }^{21}$ and later supported by infrared and UV-visible spectroscopy. ${ }^{23,24}$ Also, in our $\mathrm{H}_{2}$-TPR study, less than $0.5 \mathrm{H}_{2} / \mathrm{Me}$ was observed even for samples with the atomic $(\mathrm{Me}+\mathrm{Al}) / \mathrm{P}$ ratio of unity (MnAPO-5-2 and MnAPO-18) expected for MeAPO samples in which all metal ions replace $\mathrm{Al}$ within the AlPO framework. This dehydroxylation mechanism is consistent with the observed $(\mathrm{Me}+\mathrm{Al}) / \mathrm{P}$ stoichiometry of unity, because conversion of framework species into permanently divalent species by dehydroxylation would retain this stoichiometry, whereas the presence of extraframework phases would most likely lead to a different stoichiometry. Also, the observed decrease in the redox-active $\mathrm{Mn}$ fraction with increasing Mn loading and the loss of redox-active centers as the final temperature in $\mathrm{H}_{2}$-TPR increases for MnAPO-18 are consistent with a dehydroxylation mechanism forming these permanently divalent sites. If so, the average distance among $\mathrm{Me}-\mathrm{OH}$ species will critically determine the relative probability that such sites will undergo condensation instead of oxidation at high temperatures. Isolated reduced $\mathrm{Me}-\mathrm{OH}$ sites can only be oxidized via proton removal to form $\mathrm{H}_{2} \mathrm{O}$ in the presence of $\mathrm{O}_{2}$, but vicinal $\mathrm{Me}-\mathrm{OH}$ species can also dehydroxylate to form $\mathrm{H}_{2} \mathrm{O}$ and an oxygen vacancy. With increasing $\mathrm{Mn} / \mathrm{P}$ ratio, this would lead to lower average $\mathrm{Mn}(\mathrm{OH})-\mathrm{Mn}(\mathrm{OH})$ distances, and thus to higher recombination probabilities. A more rigorous analysis of these findings would require theoretical assessments of $\mathrm{Me}-\mathrm{Me}$ distributions in MeAPO-5 for various $\mathrm{Me} / \mathrm{P}$ ratios, as recently done for $\mathrm{Al}-\mathrm{Al}$ distributions in $\mathrm{ZSM}-5$ as a function of $\mathrm{Si} / \mathrm{Al}$ ratio. ${ }^{41}$ The importance of detemplating should also be mentioned here, as inappropriately chosen conditions during detemplating can lead to recombination before oxidation of cations via proton removal occurs.

The relative rates of dehydroxylation and oxidation can also be discussed in the context of comparisons between $\mathrm{Mn}$ and Co versions of AIPO structures. CoAPO-5 (or -18) has a lower $\mathrm{Me} / \mathrm{P}$ ratio than MnAPO-5 (or -18) (Table 1), but the redoxactive fraction is lower (Table 2), which seems inconsistent with purely statistical arguments for inactivation of redox sites via bimolecular dehydroxylation. One reason for the greater prevalence of permanently divalent sites in Co samples may be that $\mathrm{Co}^{2+}$ to $\mathrm{Co}^{3+}$ oxidation in $\mathrm{O}_{2}$ requires higher temperatures than the corresponding one-electron oxidation of $\mathrm{Mn}^{2+}$ (see Figure 2 ), thus increasing the likelihood of recombination before removal of the proton via reaction with $\mathrm{O}_{2}$. It is also possible that cation distributions are not random in AlPO frameworks and that cation pairing is more likely for Co than for Mn cations and preferred in some AlPO structures over others. For example, the disappearance of tetrahedral $\mathrm{P}$ centers in ${ }^{31} \mathrm{P}$ NMR spectra for a series of CoAPO-5 samples with varying $\mathrm{Co} / \mathrm{P}$ ratios was used to propose that Co-atoms clusters form within AlPO frameworks; ${ }^{42}$ clustering would lead to regions with high local Co contents and shorter $\mathrm{Co}-\mathrm{Co}$ distances, which would favor dehydroxylation.

If our hypothesis is correct, redox-active and permanently divalent sites arise from $\mathrm{Me}-\mathrm{OH}$ species, which lose their redox capability by forming permanently divalent structures via dehydroxylation. A rigorous evaluation of the active sites required for catalytic oxidation reactions and estimates of rigorous turnover rates require accurate measurements of the number of each type of site for each composition and thermal treatment procedure. Chemical analysis of the effluent during

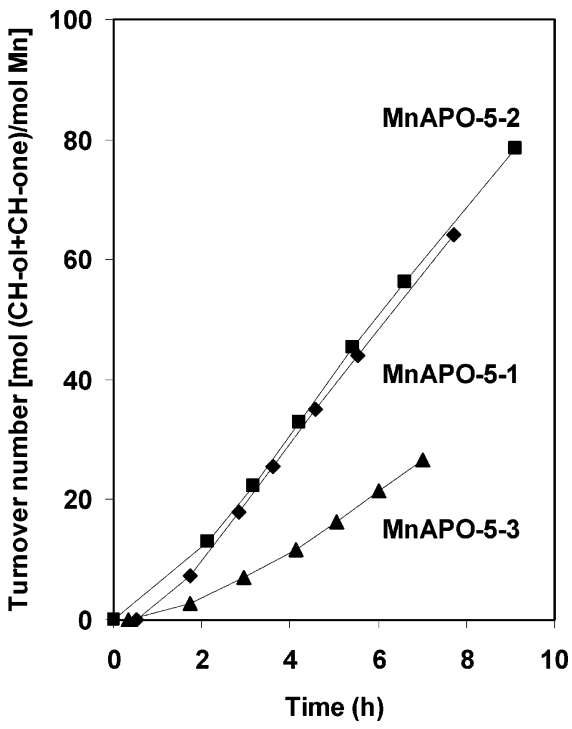

Figure 10. Cyclohexanol + cyclohexanone formation turnover number per total Mn vs contact time during cyclohexane oxidation on MnAPO5-1, MnAPO-5-2, and MnAPO-5-3 [403 K, $25 \mathrm{~mL}$ cyclohexane, 4 atm $\mathrm{O}_{2}$ (at $\left.298 \mathrm{~K}\right), 0.2 \mathrm{~g}$ catalyst].

TABLE 6: Cyclohexanol + Cyclohexanone Formation Rate Normalized by $\mathbf{M n}_{j}\left(\mathbf{M n}_{j}=\mathbf{M n}_{\text {total }}, \mathbf{M n}_{\text {redox }}\right.$ or $\left.\mathbf{M n _ { \text { nonredox } }}\right)$

\begin{tabular}{cccc}
\hline & \multicolumn{3}{c}{ turnover rate $\left[\mathrm{mol}(\mathrm{ROH}+\mathrm{R}=\mathrm{O}) / \mathrm{mol} \mathrm{Mn}_{j}, \mathrm{~h}\right]$} \\
\cline { 2 - 4 } catalyst & $\mathrm{Mn}_{\text {total }}$ & $\mathrm{Mn}_{\text {redox }}$ & $\mathrm{Mn}_{\text {non-redox }}$ \\
\hline MnAPO-5-1 & 9.11 & 14.7 & 24.0 \\
MnAPO-5-2 & 9.30 & 13.1 & 32.1 \\
MnAPO-5-3 & 5.74 & 13.4 & 10.0
\end{tabular}

$\mathrm{H}_{2}$-TPR provides a simple and accurate method for this required site speciation, which can then be used to assign catalytic relevance to the various forms of $\mathrm{Co}$ and $\mathrm{Mn}$ cations in MeAPO materials.

Involvement of Redox-Active and Permanent Sites in Catalytic Oxidation of Cyclohexane on MnAPO and CoAPO Materials. Cyclohexane oxidation has previously been studied on MeAPO materials, ${ }^{5,8,43-45}$ frequently without detailed timeresolved kinetic studies or well-characterized materials. Here, cyclohexane oxidation rates and selectivities were measured on three MnAPO-5 catalysts $(\mathrm{Mn} / \mathrm{P}=0.028-0.10)$ to assess the effect of Mn content and of reversible redox sites. Cyclohexanol $(\mathrm{ROH})$ and cyclohexanone $(\mathrm{R}=\mathrm{O})$ turnovers (per $\mathrm{Mn}$ atom) are shown in Figure 10. The relatively low conversions $(<5 \%)$ allow kinetic studies of the formation of initial products; at higher conversions, esters and acids form via secondary reactions, which introduce analytical complexities and can cause leaching of cations from inorganic structures. Cyclohexanol and cyclohexanone turnover rates (slope in Figure 10) reached constant values after $2-4 \mathrm{~h}$. These steady-state rates increased in parallel with the number of redox-active $\mathrm{Mn}$ atoms measured during reduction studies for these MnAPO-5 samples (Table 6). They were not influenced by the number of permanently divalent Mn centers, indicating that redox sites, determined from $\mathrm{H}_{2}-\mathrm{TPR}$, $\mathrm{UV}$-visible, and X-ray absorption measurements, are the only active structures for cyclohexane oxidation on these samples.

By inference from other low-temperature catalytic oxidations with homogeneous $\mathrm{Mn}$ and Co complexes and $\mathrm{O}_{2}$, reactions are assumed to occur on MeAPO materials via initial formation of cyclohexyl hydroperoxide (ROOH), which in the case of homogeneous complexes decomposes using cations in solution to form solvated $\mathrm{ROO}^{\bullet}$ and $\mathrm{RO}^{\bullet}$ radicals in initiation steps. More specifically, $\mathrm{ROOH}$ decomposition is proposed to involve $\mathrm{Me}$ - 
SCHEME 1: Cyclohexane (RH) Oxidation Pathways on Me Sites $(\mathrm{Me}=$ Mn or $\mathrm{Co})$

Initiation

$$
\begin{array}{lll}
\text { 1. }\left[\mathrm{Me}^{2+}-\mathrm{O}-\mathrm{H}^{+}\right]+\mathrm{ROOH} & \leftrightarrow & {\left[\mathrm{Me}^{2+}-\mathrm{O}-\mathrm{H}^{+}\right]-\mathrm{ROOH}} \\
\text { 2. }\left[\mathrm{Me}^{2+}-\mathrm{O}-\mathrm{H}^{+}\right]-\mathrm{ROOH} & \rightarrow & {\left[\mathrm{Me}^{3+}-\mathrm{O}\right]+\mathrm{RO}+\mathrm{H}_{2} \mathrm{O}} \\
\text { 3. }\left[\mathrm{Me}^{3+}-\mathrm{O}\right]+\mathrm{ROOH} & \leftrightarrow & {\left[\mathrm{Me}^{3+}-\mathrm{O}\right]-\mathrm{ROOH}} \\
\text { 4. }\left[\mathrm{Me}^{3+}-\mathrm{O}\right]-\mathrm{ROOH} & \rightarrow & {\left[\mathrm{Me}^{2+}-\mathrm{O}-\mathrm{H}^{+}\right]+\mathrm{ROO}}
\end{array}
$$

\section{$\underline{\text { Propagation }}$}

$\begin{array}{llll}\text { 5. } \mathrm{RO} & +\mathrm{RH} & \rightarrow & \mathrm{ROH}+\mathrm{R}^{\prime} \\ \text { 6. } \mathrm{R} \cdot & +\mathrm{O}_{2} & \rightarrow & \mathrm{ROO} \\ \text { 7. } \mathrm{ROO} & +\mathrm{RH} & \rightarrow & \mathrm{ROOH}+\mathrm{R}^{\circ}\end{array}$

\section{Termination}

8. $\mathrm{ROO}^{-}+\mathrm{ROO} \rightarrow \mathrm{ROH}+\mathrm{R}=\mathrm{O}+\mathrm{O}_{2}$

ROOH complexes and one-electron redox cycles (steps 1-4 in Scheme 1). Scheme 1 is adapted from previous proposals ${ }^{46}$ by replacing homogeneous $\mathrm{Me}$ centers with active framework $\mathrm{Me}_{\text {redox }}$ species; $\left[\mathrm{Me}^{2+}-\mathrm{O}-\mathrm{H}^{+}\right]$and $\left[\mathrm{Me}^{3+}-\mathrm{O}\right]$ represent reduced and oxidized species in reaction 1. Pathways resembling those in Scheme 1 are likely to be involved on heterogeneous catalysts, but radical-type intermediates are likely to remain adsorbed at cation sites, or at least react within microporous channels, which lack a well-defined liquid phase. Thus, it seems inappropriate to describe this oxidation as free radical-like, because alternate pathways of surface-bound intermediates may offer opportunities for specific regioselectivity in oxygen insertion steps. However, homolytic bond activation steps follow trends similar to those in radical reactions, so we use the radicallike steps proposed for homogeneous systems (Scheme 1) as a starting point in analyzing the kinetic results of this study.

Constant cyclohexanol and cyclohexanone formation rates were observed after an initial induction period indicating that all kinetically relevant intermediates reached steady-state concentrations; thus, initiation and termination rates become equal and catalyst surface coverages also reach steady-state. Rates of cyclohexanol and cyclohexanone formation initially increased with increasing $\mathrm{ROOH}$ concentration, but further increases in $\mathrm{ROOH}$ concentration did not influence reaction rates, indicating that $\mathrm{ROOH}$-derived intermediates required for product formation reached saturation coverages at active sites and that all cations form $\mathrm{Me}-\mathrm{ROOH}$ complexes. The divalent state $\left[\mathrm{Me}^{2+}-\mathrm{O}-\right.$ $\left.\mathrm{H}^{+}\right]-\mathrm{ROOH}$ was inferred kinetically to decompose more slowly than the trivalent state $\left[\mathrm{Me}^{3+}-\mathrm{O}\right]-\mathrm{ROOH},{ }^{46}$ but no direct evidence was provided. In this case, we expect that $\left[\mathrm{Me}^{2+}-\right.$ $\left.\mathrm{O}-\mathrm{H}^{+}\right]-\mathrm{ROOH}$ is the most abundant reactive intermediate (MARI) when the rates of steps 2 and 4 become equal after the induction period. Then, we can extract $k_{2}$ values $\left(k_{2}\right.$ is the rate constant for step 2 in Scheme 1) from measurements of initiation rates (which equal cyclohexane conversion rates at steady-state) and the number of redox-active sites. These $k_{2}$ values are then used for rigorous comparisons of intrinsic reactivity for redoxactive cations on different catalysts. It should be noted that the analysis is not limited to the case of step 2 as the slowest step. If radicals remain adsorbed, another step may be slower, for example the decomposition of adsorbed ROO• (step 8). Then, the nature of the rate constant would change (because it represents a different step), but the value would be the same, as the slowest decomposing intermediate would be at saturation coverage on the active $\mathrm{Mn}_{\text {redox }}$ sites. At saturation coverage, the $k_{2}$ values for MnAPO-5-1, MnAPO-5-2, and MnAPO5-3 are the same value as the rate per $\mathrm{Mn}_{\text {redox }}$ site, i.e., 14.7, 13.1 , and $13.4 \mathrm{~mol}(\mathrm{ROH}+\mathrm{R}=\mathrm{O})\left(\operatorname{mol~} \mathrm{Mn}_{\mathrm{redox}}\right)^{-1} \mathrm{~h}^{-1}$, showing an essentially constant $k_{2}$ value and, thus, a constant $\mathrm{Mn}_{\text {redox }}$ activity for these three samples.

\section{Conclusions}

During $\mathrm{H}_{2}$-TPR on MeAPO catalysts, $\mathrm{H}_{2}$ consumption, loss of $\mathrm{Me}^{3+} \mathrm{UV}-$ visible features, and a decrease in X-ray absorption edge energy occurred concurrently and at similar rates, indicating excellent agreement between these three techniques. No $\mathrm{H}_{2} \mathrm{O}$ or $\mathrm{CO}_{2}$ were detected during treatment in $\mathrm{H}_{2}$ or $\mathrm{CO}$, respectively, indicating that reduction from $\mathrm{Me}^{3+}$ to $\mathrm{Me}^{2+}$ occurred by introduction of protons rather than removal of oxygen atoms. These protons are fully removed by treatment in $\mathrm{O}_{2}$ to $773 \mathrm{~K}$.

$\mathrm{H}_{2}$ consumption rates measured during $\mathrm{H}_{2}$-TPR could be accurately described by Arrhenius-type behavior, and integrated $\mathrm{H}_{2} / \mathrm{Me}$ ratios showed that all samples contain a mixture of sites that can undergo reversible redox cycles and redox-inactive sites that cannot. After thermal treatment in $\mathrm{H}_{2}, \mathrm{UV}-$ visible spectra showed no detectable $\mathrm{Me}^{3+}$ features indicating that cations that do not undergo redox cycles remain as permanently divalent cations.

The fraction of redox cations decreased during repeated $\mathrm{H}_{2}-$ $\mathrm{O}_{2}$ redox cycles above $773 \mathrm{~K}$, indicating that redox cations can be converted into permanently divalent sites. This conversion coincides with the evolution of $\mathrm{H}_{2} \mathrm{O}$ during $\mathrm{H}_{2}$ treatments above $773 \mathrm{~K}$. These findings together with the decrease in the redox fraction with increasing $\mathrm{Me} / \mathrm{P}$ ratio are consistent with a mechanism in which $\mathrm{OH}$-groups at divalent framework sites recombine to form $\mathrm{H}_{2} \mathrm{O}$ and an oxygen vacancy.

Cyclohexanol and cyclohexanone formation rates during liquid-phase cyclohexane oxidation with $\mathrm{O}_{2}$ on MnAPO-5 samples increased linearly with the number of $\mathrm{Mn}_{\text {redox }}$ sites determined from the $\mathrm{H}_{2}$-TPR, suggesting that $\mathrm{Mn}_{\text {redox }}$ sites are the active sites for cyclohexane oxidation, and that elementary steps of this reaction require cycling between $\mathrm{Me}^{2+}$ and $\mathrm{Me}^{3+}$.

Acknowledgment. The authors acknowledge with thanks financial support from ExxonMobil Research and Engineering Co. Karl Strohmeier (ExxonMobil Research and Engineering Co) is acknowledged for synthesis of the MnAPO-18 sample used in this study. A Lavoisier grant from the French Ministry of Foreign Affairs for the support of L.O. is also gratefully acknowledged. X-ray absorption experiments were carried out at the Stanford Synchrotron Radiation Laboratory, a national user facility operated by Stanford University on behalf of the U.S. Department of Energy, Office of Basic Energy Sciences.

\section{References and Notes} 1982.

(1) Wilson, S. T.; Lok, B.; Flanigen, E. M., U.S. Patent 4,310,440,

(2) Weckhuysen, B. M.; Rao, R. R.; Martens, J. A.; Schoonheydt, R. A. Eur. J. Inorg. Chem. 1999, 565-577.

(3) Hartmann, M.; Kevan, L. Chem. Rev. 1999, 99, 635-663. 695.

(4) Hartmann, M.; Kevan, L. Res. Chem. Intermed. 2002, 28, 625-

(5) Sankar, G.; Raja, R.; Thomas, J. M. Catal. Lett. 1998, 55, 15-23.

(6) Thomas, J. M.; Raja, R.; Sankar, G.; Bell, R. G. Nature 1999, 398 , 227-230. 
(7) Wu, J. Y.; Chien, S. H.; Wan, B. Z. Ind. Eng. Chem. Res. 2001, 40, 94-100.

(8) Concepcion, P.; Corma, A.; Nieto, J. M. L.; Perez-Pariente, J. Appl. Catal. A-Gen. 1996, 143, 17-28.

(9) Da Costa, P.; Moden, B.; Meitzner, G. D.; Lee, D. K.; Iglesia, E. Phys. Chem. Chem. Phys. 2002, 4, 4590-4601.

(10) Wilson, S. T.; Flanigen, E. M., U.S. Patent 4,567,029, 1986.

(11) Chen, J. S.; Thomas, J. M. J. Chem. Soc. Chem. Commun. 1994, $603-604$

(12) Verberckmoes, A. A.; Uytterhoeven, M. G.; Schoonheydt, R. A. Zeolites 1997, 19, 180-189.

(13) Montes, C.; Davis, M. E.; Murray, B.; Narayana, M. J. Phys. Chem. 1990, 94, 6425-6430.

(14) Kortum, G. Reflectance spectroscopy, principles, methods, applications; Spinger-Verlag: New York, 1969.

(15) Meitzner, G.; Iglesia, E. Catal. Today 1999, 53, 433-441.

(16) Barton, D. G.; Soled, S. L.; Meitzner, G. D.; Fuentes, G. A.; Iglesia, E. J. Catal. 1999, 181, 57-72.

(17) Ressler, T. J. Synchrot. Radiat. 1998, 5, 118-122.

(18) Ressler, T. http://ourworld.compuserve.com/homepages/t_ressler/.

(19) Malinowski, E. R.; Howery, D. G. Factor analysis in chemistry;

Wiley: New York, 1981.

(20) Meitzner, G.; Huang, E. S. Fresenius J. Anal. Chem. 1992, 342, $61-64$.

(21) Peeters, M. P. J.; van Hooff, J. H. C.; Sheldon, R. A.; Zholobenko, V. L.; Kustov, L. M.; Kazansky, V. B. In Proceedings of the Ninth IZC; von Ballmoos, R., et al., Eds.; Butterworth-Heinemann: Washington, DC, 1993; p 651.

(22) Barrett, P. A.; Sankar, G.; Catlow, C. R. A.; Thomas, J. M. J. Phys. Chem. 1996, 100, 8977-8985.

(23) Marchese, L.; Chen, J. S.; Thomas, J. M.; Coluccia, S.; Zecchina, A. J. Phys. Chem. 1994, 98, 13350-13356.

(24) Marchese, L.; Martra, G.; Damilano, N.; Coluccia, S.; Thomas, J. M. Stud. Surf. Sci. Catal. 1996, 101, 861-870.

(25) Gianotti, G.; Marchese, L.; Martra, G.; Coluccia, S. Catal. Today 1999, 54, 547-552.

(26) Berndt, H.; Martin, A.; Zhang, Y. Microporous Mater. 1996, 6, $1-12$.
(27) Kraushaar-Czarnetzki, B.; Hoogervorst, W. G. M.; Andrea, R. R.; Emeis, C. A.; Stork, W. H. J. J. Chem. Soc., Faraday Trans. 1991, 87 $891-895$.

(28) Radev, L. N.; Penchev, V. J. React. Kinet. Catal. Lett. 1996, 58 , $139-144$.

(29) Beutel, T.; Sarkany, J.; Lei, G. D.; Yan, J. Y.; Sachtler, W. M. H. J. Phys. Chem. 1996, 100, 845-851.

(30) Wilkinson, S. G. Comprehensive coordination chemistry, 1 ed.; Pergamon Press: New York, 1987; Vol. 1.

(31) Cotton, F. A. Chemical applications of group theory, 3 ed.; Wiley: New York, 1990.

(32) Parrillo, D. J.; Pereira, C.; Kokotailo, G. T.; Gorte, R. J. J. Catal.

1992, 138, 377-385.

(33) Nakashiro, K.; Ono, Y. Bull. Chem. Soc. Jpn. 1993, 66, 9-17.

(34) Peeters, M. P. J., Ph.D. Thesis, Technische Universiteit Eindhoven, 1993.

(35) Chen, J. S.; Sankar, G.; Thomas, J. M.; Xu, R. R.; Greaves, G. N.; Waller, D. Chem. Mater. 1992, 4, 1373-1379.

(36) Thomas, J. M.; Greaves, G. N.; Sankar, G.; Wright, P. A.; Chen, J. S.; Dent, A. J.; Marchese, L. Angew. Chem.-Int. Edit. Engl. 1994, 33, $1871-1873$.

(37) Thomson, S.; Luca, V.; Howe, R. Phys. Chem. Chem. Phys. 1999. 1, 615-619.

(38) Rajic, N.; Arcon, I.; Kaucic, V.; Kodre, A. Croat. Chem. Acta 1999. $72,645-661$.

(39) Cora, F.; Sankar, G.; Catlow, C. R. A.; Thomas, J. M. Chem Commun. 2002, 734-735.

(40) Ressler, T.; Wong, J.; Roos, J.; Smith, I. L. Environ. Sci. Technol. 2000, 34, 950-958.

(41) Rice, M. J.; Chakraborty, A. K.; Bell, A. T. J. Catal. 1999, 186 $222-227$.

(42) van Breukelen, H.; Kraaijveld, G. J. C.; van de Ven, L. J. M.; de Haan, J. W ; van Hooff, J. H. C. Microporous Mater. 1997, 12, 313-322.

(43) Lin, S. S.; Weng, H. S. Appl. Catal. A-Gen. 1993, 105, 289-308.

(44) Vanoppen, D. L.; Devos, D. E.; Genet, M. J.; Rouxhet, P. G.; Jacobs, P. A. Angew. Chem., Int. Ed. Engl. 1995, 34, 560-563.

(45) Vanoppen, D. L.; Jacobs, P. A. Catal. Today 1999, 49, 177-183.

(46) Black, J. F. J. Am. Chem. Soc. 1978, 100, 527-535. 